\title{
The Law and Ethics of Restrictions on an Employee's Post-Employment Mobility
}

\author{
Norman D. Bishara* and Michelle Westermann-Behaylo**
}

Silicon Valley was built on the ability of individuals to use their knowledge and expertise to seek better employment opportunities, an idea recognized by both California law and public policy. ... . We respect trade secrets, and will defend ourselves against these claims. ${ }^{1}$

[E]very Man has a Property in his own Person. . . The Labour of his Body, and the Work of his Hands, we may say, are properly his. ${ }^{2}$

\footnotetext{
*Assistant Professor of Business Law and Business Ethics at the Ross School of Business, University of Michigan.

**Assistant Professor of Corporate Citizenship, Kogod School of Business, American University.

We would like to gratefully acknowledge the research support provided by the Ross and Kogod Schools of Business and the research assistance of Evelyn Liristis, as well as the helpful insights and thoughtful suggestions of Timothy L. Fort, David W. Hess, and Eliot P. Bates. We also wish to thank several anonymous reviewers and the editors of the American Business Law Journal for a series of useful comments and suggestions. Any remaining errors or omissions remain our responsibility. An earlier version of this article was selected as a 2011 Distinguished Proceedings Paper and as a finalist for the 2011 Holmes-Cardozo Award for outstanding scholarship by the Academy of Legal Studies in Business.
}

${ }^{1}$ Charlotte Raab, Rivals Likely to Reach for Google's "Wallet," Agence France-Presse (May 29, 2011), http://www.google.com/hostednews/afp/article/ALeqM5ikV2_xjlO6v1DSh8G0hR6Ifxe 1PQ?docId=CNG.39e901d38db6686358703e5e1cbc25ce.11 (quoting a Google spokesman commenting on a trade secret misappropriation lawsuit brought by eBay). The case alleges that a former executive of eBay's PayPal division, who had been negotiating a failed mobile payments deal between the two companies, was later hired by Google to work on the same issues using eBay's trade secrets and violating various other duties to eBay and contracts in the process.

20hn Locke, Second Treatise of Government 18 (Richard Cox ed., Harlan Davidson, Inc. 1982) (1690).

(C) 2012 The Authors

American Business Law Journal @ 2012 Academy of Legal Studies in Business 


\section{INTRODUCTION}

The skills, relationships, and knowledge bound up in a firm's employees have long been recognized as a source of important competitive advantage. ${ }^{3}$ Yet as companies increasingly rely on the strength of their human capital-in other words, their employees-for generating revenue, the potential economic harm inflicted by departing employees who move to a competitor is increasingly severe. As a result, firms are keen to use all available legal tools to restrict the post-employment mobility of their valuable employees, even as public policy may be shifting toward prioritizing employee mobility. ${ }^{4}$ This tension in the modern workplace also has business ethics implications as employers, employees, and competitors navigate these conflicting economic incentives and policy goals.

This tension between an employee's mobility and the interests of the employer is not a new development. Notably, the most used and discussed post-termination employee restrictive covenant is the covenant not to compete. These agreements have been contentious in the common law for centuries, with the earliest reported English cases dating back to the fifteenth century. ${ }^{5}$ Even in the early cases, the courts developed a rule of reason to evaluate these restrictions and "balanc[e] the social utility of certain types of restraints against their possible undesirable effects upon the covenantor and the public." ${ }^{16}$ The reasonableness test these early courts applied to covenants not to compete is still basically the same today and has received a great deal of attention by scholars, but there are two more recently developed, less understood employee-mobility restrictions that we also examine in this article, the doctrine of inevitable disclosure and garden leave. To begin to address this research gap, we take a legal analysis

\footnotetext{
${ }^{3}$ See, e.g., Sharon F. Matusik \& Charles W.L. Hill, The Utilization of Contingent Work, Knowledge Creation, and Competitive Advantage, 23 Acad. MGmt. Rev. 680 (1998) (discussing the relationship between flexible employer-employee relationships and the accumulation of knowledge for use in securing competitive advantage).

${ }^{4}$ See Michael J. Garrison \& John T. Wendt, The Evolving Law of Employee Noncompete Agreements: Recent Trends and an Alternative Policy Approach, 45 Aм. Bus. L.J. 107, 164 (2008) (finding that "recent developments signal a shift to a strict approach to [evaluating] restrictive covenants founded on a dominant policy concern for protection of employee mobility").
}

${ }^{5}$ Harlan M. Blake, Employee Agreements Not to Compete, 73 Harv. L. Rev. 625, 631 (1960) (discussing the significance of the early English cases, including the Dyer's Case in 1414).

${ }^{6} I d$. at 630 (describing the opinion in Mitchel v. Reynolds, (1711) 24 Eng. Rep. 347 (Q.B.)). 
and applied ethics approach to evaluate covenants not to compete and then inevitable disclosure and garden leave. This allows us to take an in-depth, comparative look at these restrictions and to highlight the associated problems and benefits of each in order, ultimately, to make recommendations on whether the newer concepts provide desirable alternatives to covenants not to compete. In general, we find that inevitable disclosure is highly problematic; however, garden leave, while not a perfect solution, has the potential compared to the other options to be a useful tool for managers as they seek to pursue business goals related to employee mobility and to do so in an ethically sound manner.

The continued importance of this human capital management reality and how new restrictions are entering the debate over employee freedom of job mobility are emphasized by recent news reports about Bank of America, simultaneously the United States' largest lender and deposit holder. The financial press reported that, in an apparent response to the loss of "a financial adviser with $\$ 5.9$ billion in client assets to a rival," some high-value employees of the bank's U.S. Trust unit received notice that they would be subject to a new term of employment. ${ }^{7}$ In advance of their usual bonus payments, the remaining U.S. Trust financial advisers were told they must sign a new "garden leave" provision to keep their jobs. ${ }^{8}$ The additional contract clauses changed the previous terms such that "[a]dvisers who previously could leave after two weeks notice now must remain for 60 days and are forbidden from soliciting clients for a total of eight months." 9 One observer, the president of an executive search firm, assessed the employer's actions this way: "They're sending the message, 'Make no mistake, you will incur our wrath, this is not a place you want to leave." 10 She then cautioned that "[i]t's very rare that a company would have garden-leave provisions for producers, and I think this could backfire if people view it as draconian." 11 The efforts were reportedly taken by the wealth management unit "to stem defections as rivals jockey to manage

${ }^{7}$ Hugh Son, BofA Forces 'Garden Leave' on Brokers After Defection, Bloomberg Businessweek (Feb. 18, 2011, 1:29 PM EST), http://www.businessweek.com/news/2011-02-18/bofa-forces-gardenleave-on-brokers-after-defection.html.

${ }^{8} I d$.

${ }^{9} I d$.

${ }^{10} I d$. (quoting Mindy Diamond, president of Diamond Consultants LLC).

${ }^{11} I d$. 
money for high-net-worth individuals." ${ }^{12}$ When the financial stakes are high, the lines of conflict between the interests of employers and their valuable employees become clearly defined.

In contrast to an employer's fears of employee mobility that may transfer valuable knowledge to competitors, the ease of changing jobs in the United States can be an important way for an individual to advance her career and increase her earnings. ${ }^{13}$ In difficult economic times, however, a prospective employee's leverage to negotiate the terms of employment may be diminished, while an employer's negotiation position is correspondingly strengthened. ${ }^{14}$ Though both parties are likely concerned with terms of employment that are usually negotiated, such as salary and benefits, restrictions on the employee's post-employment career mobility remain an underappreciated issue. In exchange for even an entry-level job, an enthusiastic and eager-to-please new employee may casually agree to a restrictive covenant that will have significant, unforeseen, and potentially damaging career consequences in the future.

When it comes to restrictions on an employee's post-employment freedom to take any new job she may choose, employers' and employees' interests are often in sharp conflict. In these common instances the courts, sometimes with assistance from legislatures, must balance concerns of fairness, choice of vocation, freedom of contract, economic efficiency, the public interest, knowledge transfer, and business realities. While courts routinely adjudicate these disputes over employee mobility, they seldom, if ever, discuss the ethical justifications for choosing one outcome over another. There are obviously trade-offs inherent in any contract between an employer and an employee in which the parties bargain over the work required and the compensation provided for that work. Yet, does the law adequately protect employee freedoms while allowing an employer to

\footnotetext{
${ }^{12} I d$.

${ }^{13}$ See Catherine Rampell, Many with New College Degree Find the Job Market Humbling, N.Y. Times, May 18, 2011, at A1 (discussing the current difficult job market for college graduates and the importance of moving into a better job). One economist observed, "If you don't move within five years of graduating, for some reason you get stuck where you are. That's just an empirical finding." Id. (quoting Till von Wachter, an economist at Columbia University).

${ }^{14}$ See, e.g., Kate O'Neill, Should I Stay or Should I Go? -Covenants Not to Compete in a Down Economy: A Proposal for Better Advocacy and Better Judicial Opinions, 6 Hastings Bus. L.J. 83 (2010) (advocating for courts to limit noncompete enforcement to employees with significant bargaining power to negotiate the agreement at the outset of the employment relationship).
} 
protect its hard-earned competitive advantage? Does the law favor one party over another in this instance? What is best from a societal standpoint? Should the law favor one of the parties? If so, what are the underlying principles to support that potential imbalance? Moreover, what are the ethical implications of an employer's decision to restrict the future employment choices of an employee? Also, which of the available options and justifications for restricting an employee's freedom of professional movement have the most ethical and practical grounding-and why?

While these questions persist, to date there has been little guidance for courts and policy makers on what ethical considerations surround post-employment legal restrictions upon employee mobility. Business law and employment law scholars, who in the last decade or so have focused on the fast-evolving nature of the employment relationship, provide an initial, broad view of why these legal tools and their attendant moral implications are increasingly important for employers. Some of the consistent themes inherent in this body of research are the importance of technology and knowledge management for business advantage, alongside a trend toward individualized contractual relations between employees and employers in a changing American employment market. For instance, Katherine V.W. Stone has explored the "new psychological contract" between employers and employees, which is marked by disputes over human capital development and ownership as opposed to the historical model of job security and promotions with a single firm. ${ }^{15}$ Kenneth Dau-Schmidt has examined the role of technology ${ }^{16}$ and labor contracting ${ }^{17}$ in the modern workplace. Terry Morehead Dworkin and Elletta Sangrey Callahan have detailed the use of nondisclosure agreements and measured their effectiveness against other attempts to restrict information, including covenants not to compete. ${ }^{18}$ Joan T.A. Gabel and Nancy R. Mansfield have looked at the legal implications of the "cyberspace workplace" where workers often work

\footnotetext{
${ }^{15}$ Katherine V.W. Stone, The New Psychological Contract: Implications for the Changing Workplace for Labor and Employment Law, 48 UCLA L. REv. 519 (2001).

${ }^{16}$ Kenneth G. Dau-Schmidt, Employment in the New Age of Trade and Technology: Implications for Labor and Employment Law, 76 Ind. L.J. 1, 1 (2001).

${ }^{17}$ Kenneth G. Dau-Schmidt \& Timothy A. Haley, Governance of the Workplace: The Contemporary Regime of Individual Contract, 28 Comp. Lab. L. \& PoL'y J. 313, 313-14 (2003).

${ }^{18}$ Terry Morehead Dworkin \& Elletta Sangrey Callahan, Buying Silence, 36 Am. Bus. L.J. 151, 169-71 (1998).
} 
remotely through the use of new technologies. ${ }^{19}$ Michael Garrison and John Wendt also have specifically explored the policy implications and emerging trends in restrictions on employee mobility. ${ }^{20}$

Among the assumptions that underlie the current approach to this evolving workplace are that employees are mobile and that the old paradigm of long-term and even lifetime employment with one employer are now things of the past. ${ }^{21} \mathrm{~A}$ fast-moving and competitive labor marketplace has replaced the old employer-employee arrangement. This new dynamic has been called a "high-velocity labor market," particularly in the hightech sector. ${ }^{22}$ In this context of rapid job hopping there also has been criticism of legal rules that impede the ease of mobility and the speed of this labor market. ${ }^{23}$ Moreover, the impending new Restatement of Employment Law provides further evidence that both legal scholars and practitioners are currently debating the roots and underlying values of the U.S. employment laws, including legal rules that directly implicate employee mobility. ${ }^{24}$

This article seeks to add a new dimension to this debate by examining the business law and business ethics aspects of three modern mechanisms

\footnotetext{
${ }^{19}$ Joan T.A. Gabel \& Nancy R. Mansfield, The Information Revolution and Its Impact on the Employment Relationship: An Analysis of the Cyberspace Workplace, 40 Aм. Bus. L.J. 301, 323 (2003) (providing a detailed view of the legal implications for employment relationships in a technology-driven work environment).

${ }^{20}$ Garrison \& Wendt, supra note 4.

${ }^{21}$ See, e.g., Stone, supra note 15, at 539-41.

${ }^{22}$ Alan Hyde, Working in Silicon Valley: Economic and Legal Analysis of a High-Velocity Labor Market (2003).

${ }^{23}$ Alan Hyde, Should Noncompetes Be Enforced?: New Empirical Evidence Reveals the Economic Harm of Non-compete Covenants, Regulation, Winter 2010, at 6 (adapted from a chapter in Research Handbook on the Law and Economics of Labor and Employment Law (Michael Wachter \& Cynthia Estlund eds., forthcoming 2011)).

${ }^{24}$ See, e.g., Rachel Arnow-Richman, Response to the Working Group on Chapter 2 of the Proposed Restatement of Employment Law: Putting the Restatement in Its Place, 13 Eмr. Rts. \& Emp. Pol'y J. 143, 146 (2009) ("What we have seen is a widely documented trend toward short term employment, the rise of contingent labor, the rollback of employer sponsored health plans and benefits, a reversion to external labor market practices, and, more recently, the most significant economic downturn since the Great Depression." (citations omitted)); Matthew W. Finkin, Second Thoughts on a Restatement of Employment Law, 7 U. PA. J. LAB. \& Emp. L. 279 (2005) (critiquing the underlying assumptions of the need for a Restatement of Employment Law).
} 
for restricting an employee's post-employment mobility either to a competitor or to the employee's own newly formed competing enterprise. Part I presents the background and discusses the motivations and incentives for employers to restrict their former employees' professional mobility. Next, Part II discusses the law and the associated public policy concerns of three legal mechanisms for restricting post-employment mobility: covenants not to compete, the doctrine of inevitable disclosure, and garden leave. Part III provides a business ethics critique of these mechanisms from the rights, utilitarian, and fairness perspectives. Part IV then presents recommendations for policy makers related to balancing the competing interests involved in restricting employee mobility, as well as suggestions for additional research.

\section{BACKGROUND ON EMPLOYEE MOBILITY RESTRICTIONS}

Employment mobility is generally supported by public policy and favored by employees. ${ }^{25}$ Nevertheless, employers have a valid interest in managing their current and former employees' ability to be professionally mobile. This section considers these sometimes conflicting interests, together with some of the overarching policy issues arising from the legal constraints on employee mobility.

In general, the economic mobility of employees ensures their personal freedom to pursue a livelihood of their choice, in the position where their capabilities will be most productive and where they are most likely to achieve success. ${ }^{26}$ Society benefits from maximized productivity, as well as the dissemination of skills and knowledge, which can contribute to

\footnotetext{
${ }^{25}$ See generally Garrison \& Wendt, supra note 4, at 112 (finding an "emerging trend in the law of employee noncompete agreements" indicating "that courts are generally more inclined to invalidate employee noncompete agreements than under the modern approach and that the law of employee noncompete agreements is becoming more protective of the employee's interest in mobility").

${ }^{26}$ See Wexler v. Greenberg, 160 A.2d 430, 433 (Pa. 1960) (the court aimed to "be particularly mindful of any effect our decision in this case might have in disrupting this pattern of employee mobility, both in view of possible restraints upon an individual in the pursuit of his livelihood and the harm to the public in general in forestalling to any extent widespread technological advances").
} 
innovation. ${ }^{27}$ For instance, some professionals such as lawyers and (in some jurisdictions) physicians serve a recognized public policy function, which has resulted in a prohibition on noncompetition agreements for those types of workers. ${ }^{28}$

In recent times, freedom of mobility has become increasingly more important for employees as the new psychological employment contract eschews notions of loyalty and commitment, ${ }^{29}$ thereby eliminating the security of long-term employment, pay and promotions based on tenure, and generous pensions for retirement. ${ }^{30}$ Instead, as employees shoulder the risks of economic cycles, save for their own retirements, and are paid only what globalized markets will bear, they must focus their efforts on developing the worth of their own human capital in order to ensure the marketability of their labor. ${ }^{31}$ Indeed, marketing their labor by switching jobs seems to have a large impact on employees' financial success. A recent economic study found that, among college graduates, those making three job changes at optimal points in their career gained wage increases amounting to as much as thirty-two percent compared to a graduate

${ }^{27} I d$.; see also infra Part III.B (discussing cost-benefit analysis).

${ }^{28}$ See generally Alina Klimkina, Note, Are Noncompete Contracts Between Physicians Bad Medicine? Advocating in the Affirmative by Drawing a Public Policy Parallel to the Legal Profession, 98 Ky. L.J. 131 (2009) (discussing the ban in all states on noncompetes for lawyers and arguing that physician noncompetes should be similarly prohibited).

${ }^{29}$ See Timothy L. Fort, The First Man and the Company Man: The Common Good, Transcendence, and Mediating Institutions, 36 Am. Bus. L.J. 391, 392 (1999) ( "Corporate downsizing has left the loyalty of employees unrequited. Once, an employee's loyalty and commitment to a company provided a sense of identity and meaning-employees were 'company men' . . . [; however, i]t is increasingly difficult for individuals to find a sense of long-term identity in corporate America. Indeed, in light of this emphasis on self-reliance, the common good seems merely a quaint, nostalgic phrase for today's company man. Thus, the 'company man' has become the "first man.").

${ }^{30}$ See Stone, supra note 15 , at 572 (discussing how the old employment model arose under the New Deal where "there evolved an employment system comprised of rising longevity-based wages, employer-based health insurance, and employment linked retirement security").

${ }^{31} I d$. at 570 ("It becomes clear from an examination of the writings of prominent management theorists that corporations are searching to find a way to make the shift away from long-term career employment not only acceptable, but desirable. By promising employees the opportunity to develop their human capital, the new psychological contract tries to do this. Employers promise employability and training so that, in return, employees will see themselves as entrepreneurs marketing their own human capital in a market place.”). 
making no job changes. ${ }^{32}$ Consequently, restricting employee mobility can have the effect of depressing wage levels. ${ }^{33}$

To place this discussion in a contemporary context, we consider the fast-paced modern business world in which a firm's employees hold much of the business knowledge and technological skills required to successfully operate the firm. As high technology and knowledge usage has become increasingly important, firms have come to rely on their employees (in other words, human capital) for their competitive advantage. Firms need to manage the risk of losing this advantage, particularly when those valuable employees depart to work for a competitor ${ }^{34}$ and even when that competitor is located halfway around the world..$^{35}$

A recent example from the technology sector drives this point home. The Wall Street Journal reported how Google, Inc. unveiled its Google Wallet and Google Offers concepts in advance of a summer 2011 product launch. ${ }^{36}$ Like other Google ventures into the mobile device market with its Android operating system, these technology products go beyond the company's original core search engine and advertising business model. The so-called digital wallet "will let consumers with Android smartphones pay for goods and services or receive coupons and offers by waving the phone in front of a special reader at the checkout counter." 37

Another story on the same page of the business section that day reported that eBay and its PayPal division filed a lawsuit against Google in a matter related to the very same mobile-payments business activities. ${ }^{38}$

\footnotetext{
${ }^{32}$ Rusty Tchernis, Measuring Human Capital and Its Effects on Wage Growth, 24 J. Econ. Survs. 362,378 (2010).

${ }^{33}$ Mark J. Garmaise, Ties That Truly Bind: Non-competition Agreements, Executive Compensation, and Firm Investment, 27 J.L. Econ. \& Org. 376, 414 (2009) ("Our results show that noncompetition agreements can serve as an effective means for securing employee resources within the boundary of the firm. Our findings also indicate, however, that the human capital of the firm's managers is changed by the presence of covenants not to compete.").

${ }^{34} I d$. at 382 .

${ }^{35}$ See Marisa Pagnattaro, "The Google Challenge": Enforcement of Noncompete and Trade Secret Agreements for Employees Working in China, 44 Aм. Bus. L.J. 603 (2007) (examining, in part, the complications of managing employee-possessed knowledge across international borders).

${ }^{36}$ Roger Cheng, Google Unveils Its Digital-Walled Plan, Wall Sт. J., May 27, 2011, at B3.

${ }^{37} I d$.

${ }^{38}$ Ian Sherr \& Andrew Morse, Ebay Sues Google over Mobile-Payments System, WALL ST. J., May 27, 2011 , at B3.
} 
Specifically, eBay claims "that Google poached two senior executives ... who then recruited other employees from eBay [and that] those employees used PayPal trade secrets to develop Google digital commerce products." 39 The lawsuit alleges that one of the former executives "transferred digital documents outlining PayPal's mobile-payment and point-of-sales strategies just days before leaving the company for Google. EBay says those documents were critical to its mobile-payments strategy." ${ }^{40}$ In leaving eBay, the executive took not only his personal inalienable human capital but he also allegedly misappropriated trade secrets and shared them with a competitor, breached his fiduciary duties, and violated an agreement not to solicit fellow employees. ${ }^{41}$

This dispute illustrates a modern-day dilemma that worker mobility raises for the employers, employees, competitors, and policy makers involved. In a fast-moving business world where knowledge and the individuals who create and use that knowledge are key sources of competitive advantage, the legal mechanisms available to employers have become more important than ever. ${ }^{42}$ Indeed, because of their importance and their impact on individual freedom of mobility, the underlying normative justifications for those legal mechanisms upon which courts and legislatures rely are also of great importance. To establish the motivations and stakes involved with issues of employee mobility, this part reviews why employers have significant incentives to attempt to control when their workers end the employment relationship and where they move afterwards.

As a strategic matter, employers will seek a sustainable competitive advantage over their business rivals. ${ }^{43}$ In recent years business law scholars have recognized the important role of law in achieving competitive

\footnotetext{
${ }^{39} I d$.

${ }^{40} I d$.

${ }^{41}$ See Complaint, PayPal, Inc. v. Google, Inc., No. 111CV201863 (Cal. Super. Ct. May 26, 2011), 2011 WL 2098304 (providing a detailed description of the allegations).

${ }^{42}$ See Constance E. Bagley, What's Law Got to Do With It?: Integrating Law and Strategy, 47 Ам. Bus. L.J. 587, 630-31 (2010) (using the example of the corporate lawyer's role in anticipating the inevitable disclosure of trade secrets as a way to manage the legal aspects of a potential competitive advantage over rivals).

${ }^{43}$ For a leading description of sustainable competitive advantage in the management literature, see Jay Barney, Firm Resources and Sustained Competitive Advantage, 17 J. Mgmt. 99 (1991) (widely cited as the seminal work on the resource-based theory).
} 
advantage. ${ }^{44}$ The broad applicability of this concept is demonstrated by the proliferation of scholarship in both the business $\operatorname{law}^{45}$ and management literatures ${ }^{46}$ that discusses the role of law in creating competitive advantage. To the extent that human capital is a source of sustainable competitive advantage in its business model, a firm will compete in part by seeking to exclude the human capital of its employees from use by competitors. ${ }^{47}$ In effect, a strategic employer may want to treat the human capital (i.e., the employee) as a rivalrous and excludable private good. For instance, a firm may develop a technological advantage in the form of a factory machine that belongs exclusively to the firm. Those ownership rights mean the firm can exclude others from using the machine. The technology in the machine may be patentable, in which case the firm could gain a timelimited monopoly to exclude others from utilizing it. In addition, the unique and valuable technological knowledge and processes used to create a product may qualify as a legally protected trade secret.

However, human beings are obviously not some sort of transferable, technological commodity owned by firms-despite modern employees' key role as a repository of valuable intellectual property. ${ }^{48}$ An undeniable prohibition on slavery or involuntary servitude makes it clear that employees are free to leave a job, under at-will employment or under an employ-

\footnotetext{
${ }^{44}$ See, e.g., Bagley, supra note 42 (discussing the role of law in business strategy development); David Orozco, Legal Knowledge as an Intellectual Property Management Resource, 47 Aм. Bus. L.J. 687 (2010) (describing the role of legal and regulatory acumen in finding competitive advantage in a firm's intellectual property management).

${ }^{45}$ See, e.g., Bagley, supra note 42; Robert C. Bird, Pathways of Legal Strategy, 14 Stan. J.L. Bus. \& Fin. 1, 10 (2008) (identifying categories of legal strategy that can lead to competitive advantage); Orozco, supra note 44.

${ }^{46}$ See, e.g., George Siedel \& Helena Haapio, Proactive Law for Managers: A Hidden Source of Competitive Advantage (2011); Constance E. Bagley, Winning Legally: The Value of Legal Astuteness, 33 Acad. Mgmt. Rev. 378 (2008).

${ }^{47}$ See, e.g., Matusik \& Hill, supra note 3, at 687 ("Contingent work may disseminate valuable private knowledge into the external environment, leading to the decay of competencies and a loss of competitive advantage. The departure of individuals causes a loss to the firm routines and practices in which these individuals participated." (citation omitted)).

${ }^{48} \mathrm{Cf}$. Joseph F. Phillips, Note, Inevitable Disclosure Through an Internet Lens: Is the Doctrine's Demise Truly Inevitable? 45 WM. \& MARY L. Rev. 395, 402-03 (2003) (“In terms of trade secret jurisprudence ... the employee's rights are of special importance. Preventing restrictions on freedom of job choice is one of the most basic rights that the American laborer enjoys." (citing U.S. Const. Amend. XIII, $\S 1$ (prohibiting involuntary servitude)) (emphasis added)).
} 
ment contract, and cannot be forced to work. ${ }^{49}$ While employed, the individual owes a fiduciary duty of loyalty to the employer. ${ }^{50}$ This duty of loyalty will provide the employer with some comfort that an employee will not engage in activities like competition to the employer's detriment (and potential legal recourse if the duty is breached). Employers will, however, seek to use other legal means to diminish the ability of their workers to leave and engage in damaging competition.

An initial tactic for employers is to claim ownership of a piece of knowledge in a way that it can be separated from the employee and, thus, restricted from use by that employee without the employer's permission. ${ }^{51}$ Examples of proprietary knowledge ownership held by an employer would be patent rights or, perhaps less defined, rights in proprietary trade secrets. Both patent protection, with all of its formal requirements and federal approval, and trade secret law, which arises circumstantially, are separate areas of law outside of the employer-employee relationship.

It also is true that knowledge is not bounded in the same way as other economically exploitable assets; rather, as compared to other knowledge resources, ideas are unique in that they lack boundaries. ${ }^{52}$ Because

\footnotetext{
${ }^{49} \mathrm{~A}$ classic case embodying the rule against granting the equitable relief of specific performance for personal service contracts-but allowing an injunction against working for another employer in breach of an employment contract-is Madison Square Garden Corp. v. Carnera, 52 F.2d 47 (2d Cir. 1931), in which the court granted a boxing promoter an injunction against a boxer whose intent to box for another employer violated the parties' exclusive services contract.
}

${ }^{50}$ See generally Benjamin Aaron \& Matthew Finkin, The Law of Employee Loyalty in the United States, 20 Comp. Lab. L. \& Pol'y 321 (1999) (discussing the employee duty of loyalty). See also Orly Lobel, Citizenship, Organizational Citizenship, and the Laws of Overlapping Obligations, 97 Calif. L. Rev. 433 (2009) (discussing the duty of loyalty in a new employment context of shorter employment periods and the employee's relationship to the corporation and society). In addition, nonemployee stakeholders such as members of a corporation's board of directors also will have a duty of loyalty to the entity. See, e.g., Dana M. Muir \& Cindy A. Schipani, The Challenge of Company Stock Transactions for Directors' Duties of Loyalty, 43 Harv. J. ON Legis. 437, 444-57 (2006) (discussing the duty of loyalty).

${ }^{51}$ See generally Norman D. Bishara \& David Orozco, Using the Resource-Based Theory to Determine Covenant Not to Compete Legitimacy, 87 IND. L.J. (forthcoming 2012) (discussing the separation of knowledge ownership rights between employers and employees).

\footnotetext{
${ }^{52}$ For instance, when describing the attributes of knowledge in a study of geographic mobility of engineers, two management scholars observed:

Ideas, because they have no material content, should be the least spatially-bounded of all economic activities. Being weightless, their transport is limited only by the quality and availability of communication. Since ideas serve both as the inputs and outputs in their
} 
business-valuable knowledge can be easily diffused and may lose value as it becomes dispersed, employers may try to restrict access to information such as trade secrets, and they may be more comfortable with doing that by contract instead of relying on intellectual property protections. ${ }^{53}$ In addition, employers will also make efforts to protect other proprietary information that may not rise to the level of a protectable trade secret, such as a client list.

Using contracts to achieve competitive advantage, ${ }^{54}$ employers may utilize a variety of contractual tools to manage what, from their perspective, is undesirable knowledge diffusion. Short of directly impacting employee mobility by contract, as discussed below in the context of covenants not to compete and garden leave, employers may use contracts to supplement the default legal framework for trade secret protection in their jurisdiction. For example, employee-executed nondisclosure and confidentiality agreements are contractual provisions that restrict the transfer of information and are beyond the default rule of an employee's duty of loyalty. ${ }^{55}$ These agreements seek to stop knowledge flows to competitors; however, they do not by themselves restrict an employee from engaging in competition or necessarily address employee mobility. In addition, unlike some contractual restrictions such as covenants not to compete, "[c]onfidentiality agreements ... are enforceable even in states in which anticompetition clauses are prohibited." ${ }^{56}$

own production, their location need be constrained neither by the happenstance of the spatial distribution of raw materials, energy, and labor, nor by that of demand and markets.

Paul Almeida \& Bruce Kogut, Localization of Knowledge and the Mobility of Engineers in Regional Networks, 45 Mgmt. Sci. 905, 905 (1999).

${ }^{53}$ See Kristen Osenga, Information May Want to Be Free, but Information Products Do Not: Protecting and Facilitating Transactions in Information Products, 30 Cardozo L. Rev. 2099, 2117 (2009) (citing contract law as "an appealing alternative to traditional intellectual property protection" and adding that "[b]usinesses are comfortable and familiar with contracts, probably even more so than intellectual property").

${ }^{54}$ See, e.g., Larry A. DiMatteo, Strategic Contracting: Contract Law as a Source of Competitive Advantage, 47 Aм. Bus. L.J. 724, 765 (2010).

${ }^{55}$ See Dworkin \& Callahan, supra note 18, at 169-71.

${ }^{56} I d$. at 156-57 (adding that "[c]oncerns regarding restraint of trade [as with covenants not to compete] are much less directly implicated in this context; restrictions on access to information, rather than employee movement, are involved"). 
This section has described employer motivations to restrict knowledge transfer to competitors. The next part lays out three legal mechanisms for restricting such knowledge transfer: the covenant not to compete, the doctrine of inevitable disclosure, and garden leave. Each legal restriction raises important ethical questions because these mechanisms directly address an employee's freedom of mobility after the employment relationship has ended.

\section{LEGAL MECHANISMS FOR RESTRICTING EMPLOYEE MOBILITY}

In this part, we examine three illustrative legal mechanisms used by employers to restrict the post-employment mobility, and thus freedom, of their workers. In turn, we discuss each concept along with the relevant legislation and case law that further explains how the mechanism is applied in various jurisdictions. This descriptive discussion sets the stage for Part III, where the business ethics and philosophical analysis of each concept leads to conclusions about the best use, if any, of these legal tools.

\section{A. Noncompetes}

The most widely used contractual tool for restricting an employee's postemployment mobility is the covenant not to compete. ${ }^{57}$ The covenant not to compete (also called a noncompetition agreement or simply a noncompete) comes in two types. First, it may create restrictions on postemployment competition with the employer if it is agreed to by a former employee. Second, a former owner who has sold the goodwill of the business may agree not to compete with the new owner. Non-employmentrelated covenants that fall into this second category include restrictive covenants that are often included in franchise agreements. ${ }^{58}$ In either the

\footnotetext{
${ }^{57}$ Quantifying the number of noncompetes in use-much less tracking the trend in noncompete usage and disputes over time-is difficult because most are not publicly reported. Nonetheless, scholars agree that noncompetes are increasingly being used in jurisdictions where they are enforceable. See, e.g., Gillian Lester, Restrictive Covenants, Employee Training, and the Limits of Transaction-Cost Analysis, 76 Ind. L.J. 49, 49 (2001) (stating that noncompetes "are an increasingly common feature of employment”).

${ }^{58}$ See, e.g., Michael R. Gray \& Jason M. Murray, Covenants Not to Compete and Nonsignatories: Enjoining Unfair Conspiracies, 25 Franchise L.J. 107, 107 (2006) ("Most franchise agreements
} 
post-employment or sale of a business instance, the contract restricts, for a specified time and scope, the otherwise legally permissible activities of the individual. For our purposes, we discuss only the former employee situation because of our emphasis on the ethical implications of restricting employee mobility; although other situations, such as with franchisees, may still implicate an individual's freedom of mobility and resulting ethical issues. $^{59}$

While noncompete enforcement is, on its face, an anticompetitive tactic, courts will allow enforcement when the restrictions are reasonable and legitimate business interests are being protected. ${ }^{60}$ Moreover, by definition, the post-employment noncompete that is pertinent to this article is a separate contract or contract provision between an employer and an individual employee. When accepting the noncompete the employee is voluntarily agreeing to restrictions on her otherwise lawful postemployment activities. The terms of the noncompete, thus, go beyond an employee's duty of loyalty and other fiduciary duties that apply only during the employment relationship but not after.

For example, in Mohr v. Bank of New York Mellon Corp., the plaintiffemployees had signed a "noncompetition covenant" with their former employer and a successor entity. ${ }^{61}$ The agreement provided that they "would not compete with the Mellon Corporation with any similar investment business within 50 miles of any city or town listed on a schedule to the Agreement from the later of five years from the date of closing [of the sale

today contain some form of noncompetition clause, covenant not to compete, restrictive covenant, or other agreement by the franchisee "not to compete with the franchise system it is entering, either during the term of the franchise agreement or for a period following termination of the agreement, or both.' These noncompete agreements are one of the best means available to a franchisor to protect its interest in its trademarks, service marks, trade secrets, processes, and other confidential business information." (endnote omitted)). For a detailed discussion of restrictions found in noncompetition covenants in the franchise context, see generally Robert W. Emerson, Franchising Covenants Against Competition, 80 IowA L. REv. 1049 (1995).

${ }^{59}$ For a discussion of the business encroachment phenomenon related to franchising and some of the implications for the mobility of individual entrepreneurs, see Robert W. Emerson, Franchise Encroachment, 47 Aм. Bus. L.J. 191 (2010); Robert W. Emerson, Franchise Territories: A Community Standard, 45 Wake Forest L. Rev. 779, 788-94 (2010).

${ }^{60}$ See Dworkin \& Callahan, supra note 18, at 169-70.

${ }^{61} 371$ Fed. App'x 10 (11th Cir. 2010) (unpublished opinion). 
of the original entity-employer] or twelve months after termination." ${ }^{2}$ The agreement also included language that indicated the employees understood that its violation would threaten the employer's valuable goodwill, as well as a provision that memorialized the parties' sense of the covenant's presumed reasonableness. ${ }^{63} \mathrm{In}$ addition, as other cases demonstrate, standard noncompetition agreements are often included alongside provisions addressing post-employment confidentiality, nonsolicitation of clients, and nonsolicitation of fellow employees, all of which prohibit post-employment activities that, absent these contractual terms, would otherwise be permissible. ${ }^{64}$

When looking at the legitimate interests at stake, the courts will also consider the nature and significance of the employee's skills. The New York Court of Appeals has pointed out that, "[i]n general, we have strictly applied the rule to limit enforcement of broad restraints on competition" and, in specific cases, have "limited the cognizable employer interests under the first prong of the common-law rule to the protection against misappropriation of the employer's trade secrets or of confidential customer lists, or protection from competition by a former employee whose

\footnotetext{
${ }^{62} I d$. at 12.

${ }^{63} I d$. at $13-14$.
}

${ }^{64}$ See, e.g., Zambelli Fireworks Mfg. Co. v. Wood, 592 F.3d 412 (3d Cir. 2010). In Zambelli, a fireworks company had the employee-defendant sign a noncompete that included several typical restrictive covenant provisions, including the following:

1. A clause prohibiting Wood from "engag[ing] in any manner in the pyrotechnic business" within the Continental United States or taking any position of employment with any company engaged in the sale or production of pyrotechnic displays for a period of two years after leaving Zambelli;

2. A non-solicitation provision proscribing Wood from soliciting any former customers or clients of Zambelli as well as any Zambelli employees for alternative employment for a period of two years after leaving Zambelli;

3. A confidentiality clause preventing the disclosure or use of trade secrets or any information regarding the operation of Zambelli's business;

4. A provision that Wood provide Zambelli with three months' notice of resignation;

5. A provision permitting a court to modify the terms of the 2005 Agreement in order to render it enforceable in the event the non-compete provision was found to be unreasonable;

6. A provision whereby Wood agreed to pay all legal fees, costs, and expenses if Zambelli prevailed in a legal proceeding to enforce the terms of the 2005 Agreement;

7. A choice of law provision stating that Pennsylvania law would govern the interpretation of the 2005 Agreement.

Id. at 416 . 
services are unique or extraordinary." ${ }^{65}$ As is the case in New York, some states evaluate whether an employee possesses such an extraordinary skill and expertise that a strict imposition of post-employment restrictions is necessary to protect the employer from unfair competition. ${ }^{66}$ However, not all jurisdictions require such expertise and knowledge on the part of the employee. ${ }^{67}$

In the vast majority of jurisdictions that do enforce noncompetes, courts will use a reasonableness test. A typical articulation of the reasonableness standard comes from New York's high court, the New York Court of Appeals, in BDO Seidman v. Hirshberg. ${ }^{68}$ There the court stated the common reasonableness test as follows:

The modern, prevailing common-law standard of reasonableness for employee agreements not to compete applies a three-pronged test. A restraint is reasonable only if it: (1) is no greater than is required for the protection of the legitimate interest of the employer, (2) does not impose undue hardship on the employee, and (3) is not injurious to the public. A violation of any prong renders the covenant invalid..$^{69}$

${ }^{65}$ BDO Seidman v. Hirshberg, 712 N.E.2d 1220, 1223 (N.Y. 1999) (citing Reed, Roberts Assocs. v. Strauman, 353 N.E.2d 590 (N.Y. 1976)).

${ }^{66}$ Karpinski v. Ingrasci, 268 N.E.2d 751 (N.Y. 1971) (holding that oral surgeon skills in a rural upstate New York community were not sufficiently unique and valuable to justify a refusal to enforce the contractual protection of employer); see also BDO Seidman, 712 N.E.2d 1220 (holding accountant's services and skills insufficiently extraordinary).

${ }^{67}$ For instance, some noncompete cases highlight that even low-skilled employees may be subject to noncompete enforcement actions. See, e.g., Borg-Warner Protective Servs. Corp., v. Guardsmark, Inc., 946 F. Supp. 495, 500 (E.D. Ky. 1996) (allowing noncompete enforcement against retail store security guards due to employer investment in the employees' training). Even under California law, which bans noncompetes, courts may impose geographic restrictions on employee mobility to enforce nonsolicitation of an employer's clients by former employees. See Hair Club for Men, LLC v. Elite Solutions Hair Alternatives, Inc. 2007 U.S. Dist. LEXIS 30167 (E.D. Cal. 2007) (granting an injunction based on a geographically defined client-nonsolicitation agreement with former employee-hair stylists).

${ }^{68} 712$ N.E.2d 1220, 1222-23 (N.Y. 1999).

${ }^{69} I d$. at 1223 (citation omitted). The court went on to write:

New York has adopted this prevailing standard of reasonableness in determining the validity of employee agreements not to compete. "In this context a restrictive covenant will only be subject to specific enforcement to the extent that it is reasonable in time and area, necessary to protect the employer's legitimate interests, not harmful to the general public and not unreasonably burdensome to the employee."

Id. (quoting Reed, Roberts Assocs., 353 N.E.2d at 593). 
Pursuant to one form or another of the reasonableness test, the majority of U.S. jurisdictions will enforce noncompetes to some extent. ${ }^{70}$ Research shows that most states have what can be construed as a moderate level of noncompete enforcement. ${ }^{71}$ There are, however, states that impose a virtual ban on noncompetes. ${ }^{72}$ Most famously, California has a strong, long-standing position in favor of employee freedom and against noncompetes, and the state's courts have continually upheld the ban based on public policy grounds. ${ }^{73}$ However, jurisdictions that allow postemployment noncompete enforcement will apply some version of the reasonableness test coupled with an evaluation of the stakeholders' interests. ${ }^{74}$ These states use the reasonableness test to balance the rights of the parties to the contract, as well as to consider the policy impact and the public interest. ${ }^{75}$

\footnotetext{
${ }^{70}$ See generally Covenants Not to Compete, A State-by-State Survey (Brian Malsberger ed., 2009).

${ }^{71}$ See Norman D. Bishara, Fifty Ways to Leave Your Employer: Relative Enforcement of Covenant Not to Compete Agreements, Trends, and Implications for Employee Mobility Policy, 13 U. Penn. J. Bus. L. 753,780 (2011) ("[T]he majority of states have followed a moderate course that seems to comport with traditional noncompete aesthetics of moderation through narrowly tailored and balanced-and reasonable-protectable interests that foster business investments in workers' human capital.”).
}

${ }^{72}$ The two states with near complete bans on covenants not to compete are North Dakota and California, although both states permit restrictions on post-employment competition related to an owner's sale of a business. See Norman D. Bishara, Balancing Innovation from Employee Mobility with Legal Protection for Human Capital Investment: 50 States, Public Policy, and Covenants Not to Compete in an Information Economy, 27 Berkeley J. Emp. \& Lab. L. 287, 294 n.19 (2006).

${ }^{73} \mathrm{~A}$ recent much-discussed California Supreme Court case on noncompetes addressed the public policy implications of the state's statutory ban on noncompetes. See Edwards v. Arthur Andersen, LLP, 189 P.3d 285, 293 (Cal. 2008) (reiterating California's strong public policy against enforcing contractual restraints on employment and rejecting calls for a "narrow restraint" exception); see also Bradford P. Anderson, Casenote, Edwards v. Arthur Andersen LLP: There is not a "Narrow Restraint" Exception to California's Prohibition of Noncompetition Agreements, and a General Release May Not Mean What It Says, 39 Golden Gate U.L. Rev. 163 (2009) (providing a detailed discussion of the potential policy implications of Edwards); Bradford P. Anderson, Complete Harmony or Mere Detente? Shielding California Employees from Non-Competition Covenants, 8 U.C. DAvis Bus. L.J. 8 (2007) (arguing that California's strong public policy against impinging employee mobility also weighs heavily against allowing the doctrine of inevitable disclosure in Edwards).

\footnotetext{
${ }^{74}$ See Gabel \& Mansfield, supra note 19, at 321-22.

${ }^{75}$ See, e.g., Johnson Controls, Inc. v. APT Critical Systems, Inc., 323 F. Supp. 2 d 525 (S.D.N.Y. 2004). In Johnson Controls, the court commented that,
} 
While noncompetes traditionally arise in the common law, there is a trend among many states to codify their noncompete policies. ${ }^{76}$ Several states are currently contemplating noncompete legislation, most notably Massachusetts $^{77}$ and Illinois. ${ }^{78}$ Some, such as Texas, ${ }^{79}$ have legislation outlining permissive boundaries for noncompetes. Others, such as Colorado, ${ }^{80}$ disfavor noncompetes or ban them with significant exceptions. In

[i]n fashioning the [reasonableness] analysis, New York courts have endeavored to balance public policy concerns relating to the benefits of competition and the unfettered flow of talent and ideas in our economy with employers' legitimate right to protect the fruits of their labor, the idea being that the proper balancing of these factors will produce the most wealth and innovation ... for society. It is important to keep in mind, however, that on a less grand scale the interests to be balanced are those of the individual employer and employee.

$I d$. at 533-34 (citation omitted).

${ }^{76}$ As of 2010 , seventeen states had enacted some form of legislation addressing the enforceability of noncompete covenants. See Bishara, supra note 71. These states are Alabama, California, Colorado, Florida, Georgia, Hawaii, Louisiana, Missouri, Montana, Nevada, North Carolina, North Dakota, Oklahoma, Oregon, South Dakota, Texas, and Wisconsin. Other states, such as Tennessee and West Virginia, have basic antitrust statutes that are invoked when evaluating noncompetes. See Tenn. Code Ann. §§ 47-18-104, -25-101 (2011) (disfavors any contract attempting to lessen competition); W. VA. Code § 47-18-3(a) (2011) (the state's antitrust statute).

${ }^{77}$ See Will Brownsberger, Reform Noncompete Contracts, Will Brownsberg-St. Representative, Democrat, 24th Middlesex District, http://willbrownsberger.com/index.php/endnoncompete-contracts (last visited Oct. 7, 2011) (detailing state representative's plan to resubmit his co-sponsored noncompete reform legislation to the Massachusetts legislature).

${ }^{78}$ See Winston \& Strawn LLP, HB 0016 Introduced to Create an "Illinois Covenants Not to Compete Act” (Jan. 2011), http://www.winston.com/siteFiles/Publications/Updated_HB0016_Briefing. pdf. Like Massachusetts's proposed legislation, Illinois's version of noncompete reform seeks to formalize the bounds of the traditional reasonableness test by requiring the contract to be "narrowly tailored to support the protection of a legitimate business interest" and apply it to specific levels of employees. Id. The proposal also provides for rebuttable presumptions "that a restrictive covenant is not narrowly tailored to promote a legitimate business interest if":

(i) the covenant's duration exceeds one year; (ii) the covenant's geographic area extends beyond any region in which the key employee provides employment services during the one year preceding termination of the employment relationship; or (iii) the type of services covered by the covenant extends beyond the nature of the work performed by the key employee.

Id.

${ }^{79}$ Tex. Bus. \& Com. Code $\$ 15.50$ (2010)

${ }^{80}$ The Colorado statute is titled "Unlawful to intimidate worker-agreement not to compete" and declares that "[i]t shall be unlawful to use force, threats, or other means of intimidation 
addition, new research related to the effects of noncompetes has started to create a picture of the role of these mobility-inhibiting contracts, which further sheds light on the possible economic role of restricting employee mobility. ${ }^{81}$

The post-employment implications of noncompete enforcement are clear for an affected employee. ${ }^{82}$ He is limited-at least for an amount of time and a geographic or topical scope that a court finds to be reasonable-from going to work for a competitor of his former employer or from starting a competing business. While an employee who is subject to an enforceable noncompete is prohibited from moving to a new position that is contrary to the terms of the contract, the employer has, at least in theory, already provided its consideration to support the agreement. ${ }^{83}$ In

to prevent any person from engaging in any lawful occupation at any place he sees fit." CoLo. Rev. Stat. § 8-2-113(1) (2010). However, subsection (2) provides several exceptions to this ban on noncompetes. Specifically, section (2) states:

Any covenant not to compete which restricts the right of any person to receive compensation for performance of skilled or unskilled labor for any employer shall be void,

but this subsection (2) shall not apply to:

(a) Any contract for the purchase and sale of a business or the assets of a business;

(b) Any contract for the protection of trade secrets;

(c) Any contractual provision providing for recovery of the expense of educating and training an employee who has served an employer for a period of less than two years;

(d) Executive and management personnel and officers and employees who constitute professional staff to executive and management personnel.

Id. $\S 8-2-113(2)$.

${ }^{81}$ See, e.g., Bruce Fallick et al., Job Hopping in Silicon Valley: Some Evidence Concerning the Micro-Foundations of a High Technology Cluster, 88 Rev. Econ. \& STAT. 472 (2006) (measuring higher rates of employee mobility in Silicon Valley, California's high-tech sector, as compared to other California industries or in a sample of states with enforcement of noncompetes); Garmaise, supra note 33 (finding jurisdictions that enforce noncompetes will create an environment that creates lower wages and less investment from employers in their employees); Matt Marx et al., Mobility, Skills, and the Michigan Non-Compete Experiment, 55 Mgmt. Sci. 875 (2009) (using a natural experiment created by a change in noncompete enforcement law to find lower rates of mobility under a policy of noncompete enforcement); Toby E. Stuart \& Olav Sorenson, Liquidity Events and the Distribution of Entrepreneurial Activity, 48 Admin. Sci. Q. 175 (2003) (studying the tendency of employees to become entrepreneurs after their employer-firm undergoes a dramatic change using noncompetes as one variable).

${ }^{82}$ For a discussion of the implications for other employees, see infra Part III.A.1 and accompanying footnotes.

${ }^{83}$ Some states do not require additional consideration when a noncompete is signed after employment has begun under a theory that continued employment or some additional terms or conditions of employment, such as a promise to modify an at-will employment assumption, are sufficient. See, e.g., Lake Land Emp't Grp. of Akron, LLC v. Columber, 804 N.E.2d 27 
other words, the former employer does not normally have any additional obligations once the terms of the noncompete are triggered by the termination of employment.

Again, policy makers acknowledge that noncompetes are by nature anticompetitive and would normally be unenforceable as against public policy. ${ }^{84}$ Accordingly, most state courts will allow a covenant not to compete, but "only if it is necessary to protect a legitimate business interest, reasonably limited in time and space, and consonant with the public interest." 85 While the details vary by jurisdiction, legitimate protectable business interests may include investments in training and building the employee's reputation; confidential and proprietary information, such as customer lists and strategies; and client relationships. ${ }^{86}$ In effect, most states recognize that some enforcement of noncompetes, however limited, is allowable to protect the interests of employers in sharing confidential and proprietary knowledge with their employees. This approach is consistent with the historical role of equity in adjudicating these disputes. ${ }^{87}$

In summary, even if a noncompete will lessen otherwise lawful competition and potentially inhibit the flow of knowledge, most states today will allow this compromise. Noncompetes can be controversial and have been consistently disputed in litigation. Because noncompetes create the risk that employers will overreach and improperly shift costs to employees,

(Ohio 2004) (resolving a split in the state appellate courts by concluding that an employee continuing with an at-will employment relationship is sufficient consideration to support assent to a noncompete); Rogers v. Runfola \& Assocs., Inc., 565 N.E.2d 540, 542 (Ohio 1991) (finding that a noncompete signed upon an employer's promise to a formerly at-will employee to discharge the employee only for specified causes is sufficient consideration). However, other states may require new independent consideration to support a noncompete for continuing at-will employees but not for employees who are terminable for good cause, for whom mere continued employment is sufficient consideration. See, e.g., Stone v. Griffin Communications, 53 S.W.3d 687, 693 (Tex. Ct. App. 2001).

${ }^{84}$ See, e.g., Reed, Roberts Assocs. v. Strauman, 353 N.E.2d 590, 592-93 (N.Y. 1976).

${ }^{85}$ Boulanger v. Dunkin' Donuts Inc., 815 N.E.2d 572, 577 (Mass. 2004).

${ }^{86}$ See, e.g., Hyde, supra note 23 , at 6.

${ }^{87}$ See generally T. Leigh Anenson, The Role of Equity in Employment Noncompetition Cases, 42 Ам. Bus. L.J. 1 (2005) (reviewing the history and role of the courts in the equitable analysis of noncompetes and advocating for courts to balance competing interests of employers and employees when settling noncompete disputes). 
the next sections discuss two alternative mechanisms that may still protect the employer's interests, but have a more negative impact on the employee's freedom of mobility.

\section{B. Inevitable Disclosure Doctrine}

A relatively resurgent concept that has yet to gain much traction in U.S. jurisprudence is the inevitable disclosure doctrine. ${ }^{88}$ The thrust of the concept is the assumption that a former employee who was privileged to acquire an employer's confidential information or trade secret will inevitably use or disclose the knowledge in her new employment. ${ }^{89}$ Therefore, a judicial injunction is sought to prohibit the employee from beginning the new employment based on allegations of a threatened misappropriation, coupled with irreparable harm and, to some extent in various jurisdictions, bad faith. ${ }^{90}$ Essentially, a handful of states allow an employer to argue, even in the absence of a noncompete agreement, to "enjoin a departing employee from taking a job on the grounds that he or she will 'inevitably disclose' some unspecified trade secret." 91 Inevitable disclosure developed in the common law and has seen a revival in its attempted application since the widespread adoption of the Uniform Trade Secret Act and, in particular, following the 1995 Seventh Circuit case of PepsiCo $v$.

\footnotetext{
${ }^{88}$ The doctrine also has not seen much treatment in the academic literature. Following resurgence in the debate over inevitable disclosure and its wider application to address threatened trade secret misappropriation in the mid 1990s, several student notes and comments addressed the topic. See, e.g., Jonathan O. Harris, Note, The Doctrine of Inevitable Disclosure: A Proposal to Balance Employer and Employee Interests, 78 WASH. U. L.Q. 325 (2000); David Lincicum, Note, Inevitable Conflict: California's Policy of Worker Mobility and the Doctrine of "Inevitable Disclosure," 75 S. CAL. L. Rev. 1257 (2002); Jennifer L. Saulino, Note, Locating Inevitable Disclosure's Place in Trade Secret Analysis, 100 Mich. L. Rev. 1184 (2002); Brandy L. Treadway, Comment, An Overview of Individual States' Application of Inevitable Disclosure: Concrete Doctrine or Equitable Tool? 55 SMU L. Rev. 621 (2002); Susan Street Whaley, Comment, The Inevitable Disaster of Inevitable Disclosure, 67 U. Cin. L. REv. 809 (1999). While these articles are useful, a full scholarly treatment of the subject in the business law literature is seemingly available only from Garrison \& Wendt, supra note 4, at 148-64.
}

\footnotetext{
${ }^{89}$ See Hyde, supra note 23, at 9 (criticizing New Jersey for a lack of venture capital or a culture or infrastructure of startups and pointing out that the state "vigorously enforces noncompetes" and is one of possibly three states that has supported an inevitable disclosure regime).

${ }^{90}$ See Eleanore R. Godfrey, Note, Inevitable Disclosure of Trade Secrets: Employee Mobility v. Employer's Rights, 3 J. High TесH. L. 161, 176-77 (2004).
}

${ }^{91} I d$. at 9 . 
Redmond. ${ }^{92}$ In that case, Redmond, the former executive, left PepsiCo for Quaker Oats, a competitor in the sports drink market. ${ }^{93}$ Because PepsiCo believed Redmond would inevitably disclose confidential information and trade secrets related to pricing and marketing plans, it brought suit and, eventually, was granted an injunction based on a theory of inevitable disclosure. $^{94}$

While injunctive relief based on an inevitable disclosure theory may be rare, one can imagine an employer arguing for inevitable disclosurebased injunctive relief as part of the irreparable harm contemplated by a court when evaluating a request for a preliminary injunction. ${ }^{95}$ A court could be more amenable to the argument that irreparable harm will occur initially during a time-sensitive and short-term relief of a temporary restraining order. In contrast, a long-term permanent restraining order seems less likely because of the potentially open-ended mobility restriction that would result. This concern would be particularly troubling if there were assurances that the trade secret will not be conveyed, perhaps because of an existing and enforceable nondisclosure agreement.

However, where there is evidence of wrongdoing or behavior consistent with the misappropriation of trade secrets, a court may be more likely to restrict the departing employee's choice of mobility under a theory of inevitable disclosure. For instance, in Bimbo Bakeries, Inc. v. Botticella, the Third Circuit Court of Appeals was asked to review a trade secret misappropriation case where a departing executive was one of only a few individuals with access to the plaintiff's trade secret, the process for creating famous Thomas' English Muffins "nooks and crannies." ${ }^{96}$ In the absence of a noncompete (presumably because the original employment had been in

\footnotetext{
${ }^{92} 54$ F.3d 1262 (7th Cir. 1995). For a detailed description of the PepsiCo case, the development of the inevitable disclosure doctrine, and its implications, see Garrison \& Wendt, supra note 4 , at 148-64.

${ }^{93}$ Garrison \& Wendt, supra note 4, at 153.

${ }^{94} I d$.

${ }^{95}$ Some sources assert that only a few states have embraced inevitable disclosure. See, e.g., Hyde, supra note 23, at 9 (harshly criticizing New Jersey for allowing inevitable disclosure arguments and stating that perhaps three states subscribe to the inevitable disclosure doctrine). But see Treadway, supra note 88, at 626-49 (finding in 2002 that eight states had adopted the doctrine, four states lacked definitive case law on the subject, six states adopted a limited version of the doctrine, and three states had rejected it outright).
}

${ }^{96}$ Bimbo Bakeries USA, Inc. v. Botticella, 613 F.3d 102 (3rd Cir. 2010). 
California), the appellate court reviewed the trial court's grant of a preliminary injunction prohibiting the employee from working for a competitor. After secretly accepting employment with a competitor, the employee-defendant had continued to work for the plaintiff for some time in a knowledge-sensitive role. ${ }^{97}$ Even though the employee had signed a "Confidentiality, Non-Solicitation and Invention Assignment Agreement, ${ }^{98}$ the court upheld the injunction under a theory of inevitable disclosure, at least in the short term. ${ }^{99}$

Interestingly, the Bimbo court added that there were multiple issues of public interest at play in such a case, including upholding the sanctity of confidentiality agreements and protecting trade secrets. ${ }^{100}$ The court also listed several additional interests, including "a public interest in employers being free to hire whom they please and in employees being free to work for whom they please" and citing with approval Pennsylvania precedents that had articulated "a societal interest in employee mobility." 101

As discussed below, criticism of inevitable disclosure from an ethical perspective is perhaps easier than a critique of noncompetes, because the inevitable disclosure logic allows an employer to restrict mobility without ever bargaining or paying for the right to restrict a knowledge transfer, even when that improper knowledge transfer is subconscious. ${ }^{102}$ Because it is not a contract-based remedy, an employer seeking inevitable disclosure protection is essentially arguing for a default rule to protect its intellectual property as captured in a trade secret even before there is evidence of misappropriation of that secret. The employer, thus, must ask for a court to determine that a former employee will eventually, even unconsciously,

\footnotetext{
${ }^{97} I d$. at $105-06$.

${ }^{98} I d$. at 105 .

${ }^{99} I d$.

${ }^{100} I d$. at 119.
}

${ }^{101} I d$. (citing Wexler v. Greenberg, 160 A.2d 430, 434-35 (Pa. 1960)).

${ }^{102}$ See Robin Feldman, The Role of the Subconscious in Intellectual Property Law, 2 Hastings Sci. \& Tén. L.J. 1, 12-14 (2010) (commenting that inevitable disclosure may initially appear to conflict with a trade secret approach to limiting knowledge transfer, but that "[w]ith general skills and knowledge, the law recognizes the difficulty of limiting the subconscious, declaring the information beyond the bounds of trade secret law and giving the employee free reign to use the information in a new job"). Feldman adds that, in the case of inevitable disclosure, "the law also recognizes the difficulty of limiting the subconscious, but this time, it drastically limits the employee's freedom, restricting the employee from taking a related job." Id. at 13. 
divulge or otherwise use the trade secret in competition. In effect, the remedy is a prohibition on the former employee going to work for a competitor where the trade secret will surely be used sooner or later.

Perhaps worse, the implication is that, with an application of inevitable disclosure, the restriction on mobility is not bounded in time and geographic scope, as is the case with a noncompete term that is subject to a reasonableness test. To the contrary, the information that is the subject of the trade secret in an inevitable disclosure action will be protectable-and thus the grounds to prevent the employee from moving freely-for some indefinite period that could be as long as the information remains a bona fide trade secret giving the firm a competitive advantage.

Having discussed our concerns thus far with covenants not to compete and the doctrine of inevitable disclosure, we now turn to garden leave, a less well-known contractual tool that also is designed to restrict employee mobility.

\section{Garden Leave}

Garden leave, also sometimes called gardening leave, is a relatively new mechanism for limiting post-employment mobility. Originally a concept in British law, there is some evidence that it is beginning to be used in the United States. ${ }^{103}$ Like a noncompete, but unlike the doctrine of inevitable disclosure, garden leave is a contract-based restriction on mobility, which results from the parties' negotiation. There are few discussions of garden leave in the U.S. academic literature, ${ }^{104}$ although both

\footnotetext{
${ }^{103}$ See generally Greg T. Lembrich, Note, Garden Leave: A Possible Solution to the Uncertain Enforceability of Restrictive Employment Covenants, 102 Colum. L. Rev. 2291 (2002) ("Garden leave may provide a solution to the prevailing uncertainty regarding the enforceability of restrictive covenants in the United States. Whether it will do so is a question that remains to be answered. Having observed the efficacy of such provisions across the Atlantic, many American employers in competitive industries have begun putting garden leave clauses into the contracts of their own key employees in hope that these provisions will prove to be more reliably enforceable than have the traditional post-employment restrictive covenants. As yet, however, American courts have not ruled on the legitimacy of garden leave provisions.").

${ }^{104} \mathrm{An}$ August 2011 search of all law journals for all available years in the LexisNexis database reveals only about fifteen scholarly articles mentioning garden leave in a substantive manner, and several of those exclusively deal with the Australian or British legal systems. Most of these articles merely cite a 2002 student note by Greg Lembrich. See id. At the time of that article, Lembrich's research indicated, "American courts have not ruled on the legitimacy of garden leave provisions." Id. at 2293. He added that "American commentators have also been slow to
} 
media ${ }^{105}$ and practitioners ${ }^{106}$ have noted its increasing use by U.S. employers for various types of employees.

In the case of garden leave, "the employee agrees to give notice some months prior to departure-say, six months-during which period the employer must pay the employee's salary but may choose not to assign any duties, and in any event may prevent the employee from working elsewhere." ${ }^{107}$ Thus, rather than leaving the employer and immediately beginning work for a competing enterprise, the employee is paid to remain at home and, at least metaphorically, work only in her garden. Accordingly, garden leave serves as a "means of avoiding the restraints on specific performance" because

the employer .... contract[s] for a relatively long period of notice by the employee to terminate the employment, and ... pay[s] the employee's salary during this period without requiring the employee to come into work ... on the assumption that the employee will have to stay home and work in the garden, but will be financially secure until the period of notice expires and he or she is then free to work for the competitor. ${ }^{108}$

Garden leave is like a noncompete in that it protects an employer's interest in information by limiting employee mobility, but it has the extra advantage of forcing the employer to bear those costs, post-employment, which compensates the employee. Thus, because the employer has an immediate and tangible cost to restricting mobility, the employer will refrain from using garden leave to restrict the mobility of lower-level employees

address garden leave as a potential solution to the problem [of uncertain noncompete enforcement]" and that only a few U.S. practitioner articles had addressed the subject. Id. at 2293 n.5.

${ }^{105}$ See, e.g., Joe Rauch, BofA's U.S. Trust Adding "Garden Leave" for Some, Reuters (Feb 18, 2011), available at http://www.reuters.com/article/2011/02/18/us-bankofamerica-ustrustidUSTRE71H4OZ20110218; Son, supra note 7.

${ }^{106}$ See, e.g., Thomas B. Lewis \& Mark F. Kowal, Garden Leave Provisions: A Growing Trend in Employment Agreements, N.J. L. J., Apr. 18, 2011, at S-12, available at http://www.njlawblog.com/ uploads/file/TBL\%20MFK\%20-\%20NJLJ\%20-\%204_18_11.pdf; Christopher P. Stief, What In-House Counsel Should Know About "Garden Leave" Clauses, Corporate Counsel (Oct. 22, 2008), http://www.law.com/jsp/cc/PubArticleCC.jsp?id=1202425435456 (reporting that " 'garden leave' employment agreements start to bloom in the United States").

${ }^{107}$ Cynthia L. Estlund, Between Rights and Contract: Arbitration Agreements and Non-Compete Covenants as a Hybrid Form of Employment Law, 155 U. Penn. L. Rev. 379, 425 (2006).

${ }^{108}$ Bob Hepple, The Duty of Employee Loyalty in English Law, 20 Comp. Laв. L. \& Pol'y J. 205, 214 (1999). 
who do not really have confidential knowledge. Moreover, employers will avoid paying garden leave even to top managers for longer than is necessary to protect valuable knowledge. It is, therefore, less subject than a noncompete to the criticism that an employee's right to earn a living is ignored.

The uncertainty and troublesome aspects of noncompetes have, not surprisingly, made the garden leave option more attractive in some ways to protect both employer and employee interests. As one set of practical advice from corporate lawyers has framed these issues,

American courts usually enforce noncompetes only when they are reasonable and protect an employer's legitimate business interest. As many courts value free mobility of employees and open and fair competition, courts are commonly cautious when deciding the scope and/or enforceability of noncompetes. This uncertainty has created an environment where employers may be unable to sufficiently protect their interests against departing, well-trained, highly productive employees. A "garden leave provision" may effectively protect the legitimate interests of the business while not causing a financial hardship to the employee. ${ }^{109}$

In light of the potential mutual benefits to both employers and employees provided by garden leave, and because it is less controversial than noncompete restrictions, these provisions may prove to be a popular alternative to other mobility-inhibiting mechanisms. ${ }^{110}$

Accordingly, how to determine the proper public policy balance between protecting employee mobility and regulating sensitive knowledge flows through endorsing noncompetes, the doctrine of inevitable disclosure, or garden leave remains an open question for courts and legislatures. In the next section, we go beyond simply examining the legal enforcement and business efficiency questions about restricting employees' postemployment mobility and address questions about the business ethics of such restrictions.

\section{An ETHics CRitiQue of Restrictions ON EMPLOYEE MOBILITY}

Lawmakers drafting legislation addressing employee mobility restrictions, as well as judges officiating in litigation to enforce them, may allude to

\footnotetext{
${ }^{109}$ Lewis \& Kowal, supra note 106 , at S-12.

${ }^{110}$ See, e.g., Lembrich, supra note 103, at 2314-19 (discussing several reasons why U.S. courts may find enforcing garden leave provisions preferable to enforcing noncompetes).
} 
various philosophical arguments in determining the reasonableness and public policy impacts of such measures. For example, the first step of the three-pronged test for reasonableness of noncompetes ${ }^{111}$ evaluates whether legitimate business interests are implicated, alluding to the existence of competing property rights. ${ }^{112}$ The second step assesses hardship on the employee, ${ }^{113}$ which suggests that concerns over fairness and equity may be at issue. ${ }^{114}$ The final step considers the effect on the general public, ${ }^{115}$ indicating the relevance of a utilitarian analysis-weighing the social costs and benefits of enforcing a noncompete. ${ }^{116}$ However, lawmakers and judges may not have systematically thought through the deeper philosophical basis for these arguments. To assist in this evaluation, we explore Lockean property rights and more fundamental rights, utilitarian philoso-

\footnotetext{
${ }^{111}$ BDO Seidman v. Hirshberg, 712 N.E.2d 1220, 1223 (N.Y. 1999).

${ }^{112}$ See, e.g., Hickory Specialties, Inc. v. Forest Flavors Int'l, Inc., 2000 U.S. App. Lexis 11786 (6th Cir. 2000) (unpublished decision) (addressing the enforcement of a noncompete where the issue concerned who owned property rights in trade secrets involving the process of manufacturing liquid smoke); F.S. New Prods., Inc. v. Strong Indus., Inc., 129 S.W.3d 606, 630-31 (Tex. App. 2004) (discussing how a noncompete applies to property rights in an employee's knowledge concerning the design and manufacture of trailing axle assemblies).
}

${ }^{113}$ See BDO Seidman, 712 N.E.2d at 1223.

${ }^{114}$ See, e.g., Iowa Glass Depot, Inc. v. Jindrich, 338 N.W.2d 376 (Iowa 1983) (“[W]e are required to consider the employee's situation and the surrounding circumstances in order to fairly weigh the interests of the parties."); Holland v. Brown, 156 A. 168 (Pa. 1931) (discussing whether the geographic limitation of the noncompete agreement "affords a fair protection to plaintiffs and does not oppress defendants").

${ }^{115}$ See BDO Seidman, 712 N.E.2d at 1223.

${ }^{116}$ See, e.g., Marsh USA, Inc. v. Cook, 54 Tex. Sup. Cт. J. 1234, 2011 Tex. LEXIS 465 (Tex. 2011). In Marsh USA the court wrote,

Restrictive covenants are not costless, and even a mutually acceptable noncompete can impose a deadweight loss on broader society. Courts should not confuse a noncompete's impact on the employee with its impact on competition. A restraint may be perfectly agreeable to both parties today but still harm consumers tomorrow. Moreover, as our economy becomes even more technologically advanced and knowledge-based (key contributors to a so-called high-velocity labor market), overreaching restrictions lock up human capital and decelerate the beneficial knowledge spillover that accrues from greater mobility. It remains the job of courts to be vigilant for practices that tend to servility, that deprive the public of desired services, and that quash rivals via forced restriction rather than forceful competition.

$I d$. at *64-65. 
phy developed from the writings of Bentham and Mill, and Rawlsian considerations of justice and fairness as applied to restrictions on employee mobility.

Thus, we explore frameworks from both the contractualist and the consequentialist perspectives of ethical philosophy. Other prominent perspectives within business ethics research include deontological, or dutybased, perspectives, ${ }^{117}$ and virtue ethics philosophy, an approach based on improving and acting consistently with character. ${ }^{118}$ The law governing noncompetes, however, does not appear to incorporate the consideration of duties or character. Consequently, these other ethical frameworks are beyond the scope of this article.

Turning first to the perspective of property rights, this section considers Locke's natural law arguments on the property rights to the fruits of one's labor, as well as Locke's discussion of the contractual rights of master and servant. Within this discussion we will consider the concepts of consent and freedom to contract. Locke's view will be contrasted with Werhane's conception of rights. After considering the ethics of employee mobility restrictions through a property rights lens, we will turn to a utilitarian cost-benefit analysis and then to a Rawlsian perspective on justice as fairness. We then conclude with recommendations for deeper analysis in legislative and judicial decision making regarding restraints on employee mobility.

\footnotetext{
${ }^{117}$ Deontological perspectives consider the morality of the act itself, rather than the consequences of the act. See Timothy L. Fort, Goldilocks and Business Ethics: A Paradigm That Fits "Just Right," 23 Iowa J. Corp. L. 245 (1997) (reviewing various approaches to business ethics); Edwin R. Micewski \& Carmelita Troy, Business Ethics—Deontologically Revisited, 72 J. Bus. Етнісs 17 (2007) (applying deontological ethics to evaluate cases of accounting fraud and asserting that principles of deontology should guide executive decision making).

${ }^{118}$ Virtue ethics can relate to developing and acting consistently with personal character. See, e.g., Robert Solomon, Victim of Circumstances? A Defense of Virtue Ethics in Business, 13 Bus. Eтнics Q. 43 (2003). Virtue ethics also has been applied on the organizational level to developing a "corporate character." See Geoff Moore, Corporate Character: Modern Virtue Ethics and the Virtuous Corporation, 15 Bus. Eтнісs Q. 659 (2005). Virtue ethics is often discussed in a normative manner. See, e.g., George Gotsis \& Zoey Kortezi, Ethical Considerations in Organizational Politics: Expanding the Perspective, 93 J. Bus. Етнісs 497 (2010). Moreover, because determining which virtues are important to good character may be somewhat subjective, the virtue ethics approach may be most appropriate in a case-based analysis. See, e.g., Rosa Chun, A Corporate's Responsibility to Employees During a Merger: Organizational Virtue and Employee Loyalty, 9 Corp. Governance 473, 474 (2009) (explaining "the impact of the poorly perceived organizational virtue on employees' emotional response to the merged organization”).
} 


\section{A. Property Rights Perspective}

Scholars have suggested that John Locke's concepts of property rights in one's labor and the freedom to contract out one's labor to others underlie U.S. employment law. ${ }^{119}$ Locke, in his Second Treatise on Government, spoke of the basis for property rights being deduced on a moral basis from natural law. According to Locke, natural law suggests that "every Man has a Property in his own Person. . . The Labour of his Body, and the Work of his Hands, we may say, are properly his." ${ }^{20}$ This natural property right that all persons have in their labor is necessary for subsistence and arises from every person's natural right to self-preservation. ${ }^{121}$ Locke finds there is not only an individual right to self-preservation but there is also an obligation on others to respect each person's right to self-preservation. Locke derives this right for self-preservation from the argument that humans were created as God's servants, to survive at His pleasure rather than at one another's pleasure. ${ }^{122}$ For purposes of self-preservation, mankind has the right to procure from the commons the food and drink and whatever else is necessary for survival. ${ }^{123}$ Thus, according to Locke, there is a moral basis for individuals to have property interests in their own bodies and labor, the returns of which naturally belong to those individuals.

\footnotetext{
${ }^{119}$ See Richard A. Epstein, Forbidden Grounds: The Case Against Employment Discrimination Laws 21 (1992) [hereinafter Epstein, Forbidden Grounds] ("Although that notion of ownership [of one's own labor] did not mean that every person could do exactly what he wanted, it did mean that no person could commandeer the labor of another for his own private use. The ability to use the talents of other persons depended not on coercion but rather on consent-including consent that was purchased in voluntary transactions."); see also RICHARD A. Epstein, Simple Rules for a Complex World (1995) [hereinafter Epstein, Simple Rules].

${ }^{120}$ Locke, supra note 2, at 18 .

${ }^{121} I d$. at 4-5 ("Every one, as he is bound to preserve himself, and not to quit his station wilfully; so by the like reason, when his own preservation comes not in competition, ought he, as much as he can, to preserve the rest of mankind, and may not, unless it be to do justice on an offender, take away, or impair the life, or what tends to the preservation of the life, the liberty, health, limb, or goods of another.").

${ }^{122} I d$. at 4 (" $[\mathrm{N}] \mathrm{o}$ one ought to harm another in his life, health, liberty, or possessions: for men being all the workmanship of one omnipotent, and infinitely wise maker; all the servants of one sovereign master, sent into the world by his order, and about his business; they are his property, whose workmanship they are, made to last during his, not one another's pleasure.").

${ }^{123} I d$. at $17-18$ ("Whether we consider natural reason, which tells us, that men, being once born, have a right to their preservation, and consequently to meat and drink, and such other things as nature affords for their subsistence....").
} 
When it comes to one's property rights in one's self, Locke suggests that, under the terms of natural law, "man . . cannot, by compact, or his own consent, enslave himself to any one, nor put himself under the absolute, arbitrary power of another." ${ }^{124}$ Nevertheless, Locke recognizes that an individual has the freedom to trade or exchange property that is the fruit of his labor, as well as trading the labor itself. Thus, in "a state of perfect freedom [men are free] to order their actions, and dispose of their possessions and persons, as they think fit, within the bounds of the law of nature." ${ }^{125}$ In this light, Locke recognizes that a man is free to sell his services for wages, which "gives the master but a temporary power over him, and no greater, than what is contained in the contract between 'em." 126

In this way, the concept of freedom to contract becomes relevant in Locke's philosophy, as well as the strict interpretation of contractual terms. During the time of the contract between master (employer) and servant (employee), Locke indicates that the labor of the servant belongs completely to the master: "Thus the grass my horse has bit; the turfs my servant has cut;... become my property.... The labour that was mine, removing them out of that common state they were in, hath fixed my property in them." 127 These clauses are relevant to a consideration of legal restrictions on employee mobility from a rights-based ethical framework.

The master's (employer's) ownership of the product of the servant's (employee's) labor is well recognized today. Modern scholars acknowledge that businesses can have property rights in the capital, technology, and information used by employees to contribute productively to the business, as well as property rights to the results of the employee's production. ${ }^{128}$ Nevertheless, Werhane suggests that property rights are secondary to more fundamental moral rights, such as freedom and the equal opportu-

\footnotetext{
${ }^{124} I d$. at 15 (emphasis omitted). This position has been criticized in the literature, given that Locke invested in the slave trade and had a role in drafting the Carolina constitution, which accounts for the practice of slavery. See, e.g., Jennifer Welchman, Locke on Slavery and Inalienable Rights, 25 Can. J. Phil. 67 (1995).

${ }^{125}$ Locke, supra note 2, at 3 (emphasis omitted).

${ }^{126} I d$. at 50 (emphasis omitted).

${ }^{127} I d$. at 19.

${ }^{128}$ See, e.g., Patricia H. Werhane et al., Employment and Employee Rights (2004); Patricia H. Werhane, Persons, Rights, and Corporations 21 (1985).
} 
nity to self-development. ${ }^{129}$ These more fundamental rights may bring about the necessity for compromise when it comes to protecting property rights. These considerations are relevant in the evaluation of public policy on legal restrictions to employee mobility, as discussed in the following sections.

\section{Noncompetes}

Under Locke's concept of freedom to contract labor services, individuals are free to agree to contractual terms detailing the duration and extent of the relationship between master and servant. When it comes to noncompetes, however, what is at issue is the ownership and deployment of the productive capacity represented by the employee's knowledge, skills, and talents beyond the termination of the labor contract. Noncompetes controversially allow the former employer to assert a continuing right in restricting the employee's use of that productive capacity after the employee is no longer working for that employer, nor receiving continued compensation, nor bound by the normal common law duties of loyalty to a current employer. ${ }^{130}$

Obviously, this continuing, postcontractual right is quite valuable to the employer, intent on reducing the threat of competition after an employment contract is terminated and an employee has departed. But noncompetes can also be beneficial to employers even while the employment contract is still in force. Noncompetes allow the employer to increase the predictability of access to an important resource, in this case a human resource, by raising the opportunity cost of the employee leaving to work for a competitor. ${ }^{131}$ In other words, this is a strategy for reducing the flight risk of valuable employee assets. Accordingly, with the greater certainty of

\footnotetext{
${ }^{129}$ Werhane, supra note 128 , at 21-22 ("It must be acknowledged, however, that private ownership is not on a par with the most basic rights .... What we wish to show is that a private enterprise economic system that recognizes private ownership as a moral right is not antithetical to individual liberty, in particular the freedom to develop autonomously one's own life.").

${ }^{130}$ See Rachel Arnow-Richman, Bargaining for Loyalty in the Information Age: A Reconsideration of the Role of Substantive Fairness in Enforcing Employee Noncompetes, 80 OR. L. REv. 1163, 1182-85 (2001); supra Part II.A.

${ }^{131}$ See generally Paul H. Rubin \& Peter Shedd, Human Capital and Covenants Not to Compete, 10 J. Legal Stud. 93 96-99 (1981) (analyzing restrictive employment covenants in terms of the distribution of training costs and the incentives that training creates).
} 
staffing that comes with an enforceable noncompete, an employer is more likely to invest in the employee by investing in valuable human capital. ${ }^{132}$ Noncompetes are also important to employers in that they can be used defensively when they contain antipoaching or antiraiding provisions that not only prohibit a former employee from competing, but also prevent the employee from eviscerating the former employer's staff by luring away the best and brightest workers.

An additional argument supporting these restrictions is that a noncompete is a contract clause that, like any contractual issue, is binding only upon mutual consent. Locke suggests that an individual has the freedom to consent to any agreement to sell her labor services-that is, to become a servant to a master or an employee to an employer. ${ }^{133}$ Where consent is given, the fruits of the employee's labor belong to the employer to the full extent of the agreed-upon contractual terms. ${ }^{134}$ The initial question that begs to be answered is, how does one define consent? Locke asserts that natural law limits the freedom to contract at the point where doing so would involve consenting to arbitrary constraints on an individual's right to liberty, such as constraints amounting to enslavement or constraints on an individual's right to subsistence and self-preservation. ${ }^{135}$ As has been noted, the definition of consent can be troublesome because consent comes very close to coercion when one agrees to go along with an action due to lack of information or simply because no other feasible option is available. ${ }^{136}$ Yet, as discussed below, because of unequal bargaining power, employees often find they are required to sign nonnegotiable, boilerplate noncompetes if they want to keep their jobs. ${ }^{137}$

\footnotetext{
${ }^{132}$ See Bishara, supra note 72 , at 304.

${ }^{133}$ Locke, supra note 2, at 3.

${ }^{134} I d$. at 50 .

${ }^{135} I d$; see also id. at $15-16$.

${ }^{136}$ Michael Keeley, Continuing the Social Contract Tradition, 5 Bus. Ethics Q. 241, 241 (1995) (questioning "the concept of consent as a viable ethical criterion" and arguing "for an alternate principle of impartiality as a more appropriate moral norm in a social contract theory of organizations").

${ }^{137}$ See Rachel Arnow-Richman, Cubewrap Contracts: The Rise of Delayed Term, Standard Form Employment Agreements, 49 Ariz. L. Rev. 637, 649 n.60 (2007) ("Courts have generally rejected claims brought by employees fired for refusing to sign a noncompete." (citing Maw v. Advanced Clinical Commc'ns, Inc., 846 A.2d 604, 611 (N.J. 2004) (holding that termination
} 
Professor Richard Epstein has evaluated how Locke's concepts of property rights in one's labor and the freedom to contract out one's labor to others underlie U.S. employment law. ${ }^{138}$ Under freedom of contract, there may be an assumption that employers and employees agree to complete contracts, with all the terms fully negotiated, understood, and spelled out. ${ }^{139}$ In this sense, if an employee accepts in advance that a noncompete covenant is part of the bargain, is the subsequent enforcement of that agreement a violation of the employee's rights? In a Lockean freedom to contract world, the answer may be "no"; otherwise, what is the point of such contracts? However, it seems inconsistent with a Lockean concept of property in one's person to hold a noncompete clause to be binding when the terms of the contract were not presented until after one started working, which is when one has declined any other prospective job offers. Further, is it even possible for the employee to consent to a noncompete covenant if she does not fully understand what she may be giving away at some future point? To what extent would an employee truly understand the value of her skills at some unspecified point in the future? Even if the employee were to have full awareness of the rights she is giving away in a noncompete, there is the question of whether the employee has an equal and free ability to negotiate these terms. As discussed below, several critiques have been put forward regarding the employee's consent to waive future rights, as occurs with a noncompete. Next, we will consider how a rights-based perspective might weigh in on these debates.

Freedom of contract assumes that the terms of a contract are freely negotiated. However, in the current employment context, the terms of a noncompete are not necessarily open for negotiation. As such,

[t]he new model of private ordering in employment relies on boilerplate documents, unilaterally drafted by the employer and presented as a condi-

for refusal to sign overbroad noncompete did not give rise to claim of wrongful discharge in violation of public policy))).

\footnotetext{
${ }^{138}$ See Epstein, Forbidden Grounds, supra note 119, at 21.

${ }^{139}$ Richard A. Epstein, In Defense of the Contract at Will, 51 U. CHI. L. Rev. 947, 955 (1984). But cf. Mark Roehling \& Wendy Boswell, "Good Cause Beliefs" in an "At-Will World"?: A Focused Investigation of Psychological Versus Legal Contracts, 16 Emp. Resps. \& RTs. J. 211 (2004) (revealing that employees' beliefs regarding job security are much stronger than the rights reflected in the terms of their contracts, based on an empirical exploration comparing employees' assumptions about their employment contracts to the actual legal contractual terms).
} 
tion of employment, often subsequent to the start of work. Their purpose is not to memorialize a negotiated set of terms, but to extract waivers of rights, thus realigning statutory and default rules to better reflect employers' interests. $^{140}$

Stone suggests that, earlier in history, courts were very suspicions of noncompetes in employment relationships because "they were often the result of vastly uneven bargaining power and thus contracts of adhesion." 141 The tides have shifted, though, and many authors have discussed the legal and ethical implications of differences in bargaining power between employees and employers. ${ }^{142}$

Many factors may limit an employee's ability to negotiate the terms of a noncompete agreement. For example, the employer's timing in proffering the noncompete may affect the balance of bargaining power. As ArnowRichman notes, the employer can require the employee to sign a noncompete at the point when the employee accepts the job or at some point after the employee has started working. ${ }^{143}$ Cognitive reasons may make it difficult for an employee to fully appreciate what she is agreeing to in signing a noncompete when she accepts a job. ${ }^{144}$ At the beginning of an employment relationship, employees tend to be optimistic about their

\footnotetext{
${ }^{140}$ Arnow-Richman, supra note 137, at 639.

${ }^{141}$ Katherine V.W. Stone, Knowledge at Work: Disputes over the Ownership of Human Capital in the Changing Workplace, 34 Conn. L. Rev. 721, 721-63 (2001).

${ }^{142}$ See, e.g., Gerhard Blickle \& Alexander Witzki, New Psychological Contracts in the World of Work: Economic Citizens or Victims of the Market? 3 Soc'y \& Bus. Rev. 149 (2008) (describing the underlying causes for changes in employment conditions and presenting empirical findings on individuals coping with career changes); David Hart \& Jeffrey Thompson, Untangling Employee Loyalty: A Psychological Contract Perspective, 17 Bus. Етнісs Q. 297 (2007) (viewing loyalty as a cognitive phenomenon, presenting a framework that defines the construct, and anticipating obligations and asymmetries in loyalty); Pauline T. Kim, A Study of Worker Perceptions of Legal Protection in an At-Will World, 83 Cornell L. Rev. 105 (1997) (finding that workers overwhelmingly misunderstand legal rules governing employment relationships, overestimating job protections and employee rights).

${ }^{143}$ Arnow-Richman, supra note 137, at 639.

${ }^{144}$ See, e.g., Melvin Aron Eisenberg, The Limits of Cognition and the Limits of Contract, 47 STAN. L. Rev. 211, 251-52 (1995) (showing that limits of cognition explain many limits on the bargain principle, that a contracting party will act with full cognition to rationally maximize his subjective expected utility). Eisenberg argues that classes of contract provisions and classes of contracts, such as employment contracts, are systematically affected by the limits of cognition, such that the premise of the bargain principle is not fulfilled. Id.
} 
future with that firm. ${ }^{145}$ This has been compared to the period of courtship, where a suitor is unlikely to raise questions about the end of the relationship and risk appearing not committed to its success. ${ }^{146}$ At the start of an employment relationship, employees are not likely to be anticipating reasons they might be later interested in an employment opportunity with another employer, or at least they are reluctant to acknowledge that when starting a new job. In addition, at the outset, employees may not anticipate the hardship of being unable to work in their chosen field for a year or maybe even up to three years. ${ }^{147}$ Employees are not likely to think about the fact that their skills could be rendered obsolete if they are required to spend a significant amount of time outside of their field, which could damage their future ability to sell their skills and services to other employers.

Noncompetes are also often required as a condition of continued employment when an employee has already been working for the firm for some time. It may be more difficult for the employee to decline to sign a noncompete agreement, as she has not been on the job market recently and does not readily have other employment options. In many states, an offer of continued employment is legitimate consideration for signing a noncompete, ${ }^{148}$ meaning that the employee may be in the position of having to sign the agreement or immediately leave the firm. ${ }^{149}$ This takeit-or-leave-it approach certainly limits employee bargaining power to

\footnotetext{
${ }^{145}$ Viva R. Moffat, The Wrong Tool for the Job: The IP Problem with Noncompetition Agreements, 52 WM. \& MARY L. Rev. 873, 891-92 (2010).

${ }^{146} I d$. at 891 \& n.58 (citing Samuel Issacharoff, Contracting for Employment: The Limited Return of the Common Law, 74 Tex. L. Rev. 1783, 1794-95 (1996)).

${ }^{147}$ See Moffat, supra note 145 , at 886 \& n.43 (citing Restatement (Second) of Contracts $\S 188$ cmt. g (1981)). Moffat notes that "[t]he drafters of the Restatement (Third) of Employment Law have apparently struggled with the proper approach to take. The draft provision permits limited enforcement of noncompetes, and it does not appear to acknowledge the bargaining process concerns.” Id. (citing Restatement (Third) of Employment Law $§ 8.06$ (Preliminary Draft Nov. 7, 2010)).

${ }^{148}$ See Bishara, supra note 71, at 776, 792 fig.10 (mentioning the policies of some states that provide for continued employment to serve as sufficient legal consideration for a covenant not to compete).

${ }^{149}$ See O'Neill, supra note 14, at 84 (arguing that courts should "minimiz[e] the enforcement of covenants not to compete where the assenting employee lacks significant bargaining power while preserving employers' abilities to enforce these covenants against employees who enjoy such power" as a safeguard for vulnerable employees).
} 
negotiate the terms of a noncompete. By contrast, the bargaining power prior to employment is perhaps not as limited because, at least at that moment, the employee could turn down the employment offer. Although this may be unrealistic in that the employee may still have difficulty in properly valuing the cost of a restriction that is buried among other terms in the agreement and that is not triggered until the potentially distant termination.

Noncompete clauses also may be proffered at the end of an employment relationship. Which party holds the stronger bargaining power could completely depend upon the circumstances-for instance, whether the employer or employee is about to terminate the relationship. Where the employee is planning to move on to another job, she may have little incentive to offer the employer any protection against unfair competition. But, where the employee has been fired, the employer holds all the bargaining power, and the employee may be fully cognizant of the hardship that a noncompete may bring as she anticipates a stretch of time without employment in her chosen field. ${ }^{150}$

Some argue that public policy does not favor limitations of employee mobility; however, evidence suggests that litigation to enforce noncompetes is more prevalent than ever before, and courts are more likely than before to uphold them. ${ }^{151}$ Given the implications of a knowledge-based economy, ${ }^{152}$ there is little surprise that courts might favor employers' interests to a greater extent. Further, emboldened by their strong negotiating position, employers may draft extensive noncompete clauses, which if reviewed in litigation, might be found unreasonable by the courts. In states where "blue-penciling" contract modification is permitted, there is no risk to the employer who overreaches because courts will not throw out an unreasonable noncompete, but rather will redraft the clause to comport with what the court finds to be reasonable. ${ }^{153}$ Where boilerplate noncompete terms are used, the unbearably high costs of challenging the noncompete restrictions in court and the uncertainty of the outcome of a judge's decision might

\footnotetext{
${ }^{150} I d$.

${ }^{151}$ Bishara, supra note 72 , at 290 n.6.

${ }^{152}$ See Bishara \& Orozco, supra note 51.

${ }^{153}$ See Bishara, supra note 71 , at 776-77.
} 
have a chilling effect on any employee's interest in fighting against the terms or seeking alternative employment in her field. ${ }^{154}$

Regardless of when the noncompete was signed by the parties, the enforcement of a noncompete is triggered only at the point of a decision, on either side, to end the employment relationship. At that point, the employee may acquiesce to the terms of the agreement without a fight or ignore it, causing the employer to go to court to enforce the noncompete. ${ }^{155}$ The court process can be lengthy and costly for both parties, and the court's determination of what is reasonable in the circumstances can produce an outcome that neither party expected. Thus, in any particular circumstance where parties sign a noncompete agreement, the actual impact of the clause and, therefore, what the employer and employee are consenting to would be more and more uncertain the further removed the parties are from the point of both contract signature and the triggering event.

The rights-based perspective may not anticipate the difficulties of the nature of consent versus coercion, because freedom to contract is arguably a natural right to be exercised by individuals as equals. ${ }^{156}$ In a masterservant relationship such as that of employer-employee, the contract transfers powers over the servant to the master, to the extent of the time period and other terms consented to by the parties to the contract. Even with consent, under a rights-based perspective the actual outcome may be bounded by the party's absolute and fundamental rights, such as Locke's preclusion against enslaving oneself $f^{157}$ and the right prioritized by Werhane to self-development. ${ }^{158}$

\footnotetext{
${ }^{154}$ See Earthweb, Inc. v. Schlack, 71 F. Supp. 2d 299, 310 (S.D.N.Y. 1999) (noting that a noncompete "can be a powerful weapon in the hands of an employer [as] the risk of litigation alone may have a chilling effect on the employee"); Rachel Arnow-Richman, Cubewrap Contracts and Worker Mobility: The Dilution of Employee Bargaining Power via Standard Form Noncompetes, 2006 Мich. Sт. L. Rev. 963, 966-67 (“[C]ubewrap noncompetes succeed in further diluting an employee's already tenuous grip on any form of bargaining power. They strip away the worker's ability, both at the outset and during the course of employment, to refuse to deal."); Stewart E. Sterk, Restraints on the Alienation of Human Capital, 79 VA. L. Rev. 383, 410 (1993) (observing that "by limiting the number of attractive alternatives available to an employee, a restrictive covenant may ... 'coerce' that employee to remain with his initial employer").

${ }^{155}$ See supra Part II.A (describing the noncompete enforcement procedures).

${ }^{156}$ See Epstein, Forbidden Grounds, supra note 119, at 20-27.

${ }^{157}$ See Locke, supra note 2, at 15.

${ }^{158}$ See Werhane, supra note 128 , at $18-19$.
} 
Thus, the weaknesses of noncompetes from the rights-based perspective include (1) a failure to resolve the issues of employee consent versus coercion to protect against employer overreaching, (2) questions about the employee's ability to develop herself and make a living from her property rights in her own productive capability, and (3) a failure to gain certainty about protection of the employer's property rights to competitive information such as trade secrets. Greater certainty and better protection of the interests of both sides would be more beneficial for society. Next we will consider a rights-based point of view on two other forms of employeemobility restrictions to determine whether these mechanisms better ensure that interests in certainty and protection of property rights are available to both employers and employees.

\section{Inevitable Disclosure Doctrine}

As discussed above, the inevitable disclosure doctrine results in a judicially enforced injunction giving employers rights to restrict employee mobility beyond the term of the employment contract. ${ }^{159}$ The doctrine provides that "employers may enjoin a departing employee from taking a job on the grounds that he or she will 'inevitably disclose' some unspecified trade secret." 160 This doctrine is intended primarily to prevent the employee from revealing information like a trade secret that is the property of the employer, where revelation of that information would decrease its value and/or impair the employer's competitiveness. ${ }^{161}$ Accordingly, an employer may restrict a former employee from joining a competitor if disclosure of confidential information would be inevitable in that new employment setting. The doctrine does not specifically have the goal of restraining the productive capacity of the employee, although that is the ultimate effect. Consideration of this doctrine implicates both the rights-based concerns for protecting the employer's property rights on the one hand and the employee's right to self-development on the other.

Where the employer has invested efforts in developing the information as valued property (e.g., trade secrets) and relies upon the property for continued competitiveness, Lockean analysis would support the

\footnotetext{
${ }^{159}$ See Hyde, supra note 23, at 6 .

${ }^{160} I d$. at 9.

${ }^{161} I d$.
} 
employer's right to protect that property from the encroachment of others. ${ }^{162}$ Locke posits that ownership requires continued use of property. ${ }^{163}$ Thus, when the employer's company information related to its competitive strategy is at issue, Lockean analysis could be used to defend measures to protect that property.

Alternatively, because the ultimate effect of the inevitable disclosure doctrine is to hinder the former employee's ability to use his skills in the type of work that may be his highest productive capacity, this doctrine bumps up against two important rights considerations: first, the right of individuals to protect their own self-preservation and, second, the freedom of contract as applied to the terms of the master-servant relationship. ${ }^{164}$ Criticism of inevitable disclosure is perhaps even easier than critiques of noncompetes because the inevitable disclosure logic allows an employer to restrict mobility without ever bargaining or paying for the right to restrict a knowledge transfer. As discussed above, Locke specifies that an agreement to sell one's services gives the "master" limited power only as contained in the contract. ${ }^{165}$ Given that the inevitable disclosure doctrine gives the employer powers over the employee that are not covered by an agreement between them, Locke's view of freedom to contract would be undermined by the employer's ability to restrict employment opportunities under the inevitable disclosure doctrine. ${ }^{166}$ Moreover, Locke argues for an individual right to self-preservation, as well as an obligation on others to respect each person's right to self-preservation, and against any attempt to "take away, or impair the life, or what tends to the preservation of the life,

\footnotetext{
${ }^{162}$ Locke, supra note 2, at 18-24.

${ }^{163} I d$. at 24 ("[W] hatsoever he tilled and reaped, laid up and made use of, before it spoiled, that was his peculiar right .... But if either the grass of his enclosure rotted on the ground, or the fruit of his planting perished without gathering, and laying up, this part of the earth, notwithstanding his enclosure, was still to be looked on as waste, and might be the possession of any other.").

${ }^{164} I d$. at $17,50$.

${ }^{165} I d$. at 50 .

${ }^{166}$ While property rights and freedom of contract are valued in Lockean analysis, Epstein suggests that a limited role for the state in ensuring these rights is preferable. Epstein notes, "The unquestioned right to quit or to fire has powerful and desirable incentive effects. In particular, it serves as an effective check against the advantage-taking open to either side in a continuous relationship." Epstein, Forbidden Grounds, supra note 119, at 159.
} 
liberty, health, limb, or goods of another." 167 The rule of inevitable disclosure could potentially be used to block an employee indefinitely from work in his chosen field, for as long as the employer's information (e.g., trade secrets) is protected property. Thus, to the extent the employee's right of self-preservation is injured by actions of the employer that step beyond the agreed-upon terms of their relationship, a Lockean analysis would find the doctrine of inevitable disclosure lacking.

\section{Garden Leave}

The concept of garden leave accomplishes many of the goals sought under the other employee mobility constraints discussed above, without incurring many of the negative impacts on the freedom of contract and the right of self-preservation. Locke's key concern of protecting property rights is ensured yet appropriately limited in duration by the price mechanism. Freedom of contract is promoted in this instance because the details of the garden leave would be set forth in an initial employment contract to which both parties consent. Whereas the noncompete clause provides the employer with unilateral rights and binds the employee with duties, the garden leave agreement generates bilateral rights and duties on the part of both the employer and employee. ${ }^{168}$ For this reason, garden leave provides mechanisms to protect each party's property rights, while limiting overreaching on either side. The employer's interest in protecting property rights in competitive information is ensured, and that protection lasts only for the period of time that the employer is willing to pay compensation (the price mechanism). The employee preserves her interest in making a living and protecting her rights to her productive capacity in the long run. In the short run, although the employee would not actively use her productive capacity in her chosen field, she would be fairly compensated for that period. Finally, where the contract very clearly establishes the relevant duration of garden leave, there would be a limited role of the state and a

\footnotetext{
${ }^{167}$ Locke, supra note 2, at 5.

${ }^{168}$ During the mandatory notice period, the garden leave agreement requires the employee to continue employment with the employer-with all the attendant duties of loyalty-while the employer is required to continue paying the salary and benefits due to the employee under the contract. See, e.g., Maltby v. Harlow Meyer Savage, Inc., 633 N.Y.S.2d 926, 930 (N.Y. Sup. Ct. 1995) (finding a garden leave provision reasonable and explicitly noting that the payment of base salary "protects the employee's livelihood").
} 
lower level of scrutiny in adjudicating the employer-employee relationship. ${ }^{169}$ From a Lockean point of view, the garden leave mechanism may be better in preserving the bilateral rights of the individuals involved. Moreover, it is consistent with the Lockean natural rights tradition, "which protects natural property rights and allows the state to restrict them only as necessary to protect the property owner and his property from force and fraud." 170

\section{B. Utilitarian View}

While a Lockean analysis focuses on individual rights with a limited role for the state, a utilitarian perspective can be used to determine whether employee mobility restrictions are beneficial from a public policy perspective. Utilitarian analysis typically takes an ends-based, rather than meansbased view to evaluate the morality of an outcome, with the goal of producing the greatest amount of happiness for the greatest number of people. ${ }^{171}$ Generally, utilitarian theory applies a cost-benefit analysis not only to the interests of individual parties but also to the overall outcomes for society. ${ }^{172}$ Thus, to determine the ethics of mobility restrictions we could weigh the benefit gained by employers, employees, and greater

\footnotetext{
${ }^{169}$ See Daniel J. Raker, A Lower Level of Scrutiny?: New Alternatives for an Effective Restraint on Competitive Activity, 39 Loy. U. CHI. L.J. 751 (2008).

${ }^{170}$ James E. Macdonald \& Caryn L. Beck-Dudley, A Natural Law Defense to the Employment Law Question: A Response to Richard Epstein, 38 Aм. Bus. L.J. 363, 410 (2001).

${ }^{171}$ See generally John Stuart Mill, Utilitarianism (Oskar Priest ed., Bobbs-Merrill Co. 1957) (1863). Mill refines and develops the philosophical proposal of Jeremy Bentham (utilitarianism), which is a moral theory based on the principle that an action is morally right if its consequences lead to happiness (absence of pain) and wrong if it ends in unhappiness (pain). Id.

${ }^{172}$ It has been recognized that delimiting the community or population to be considered in determining the greatest good in a utilitarian analysis is problematic. See, e.g., Gerald J. Postema, Interests, Universal and Particular: Jeremy Bentham's Utilitarian Theory of Value, 18 Utilitas 109, 129 (2006) ("[S]erving particular interests is not the sort of enterprise that one can get all the others in the community to join. It is precisely because particular interests may point in very different directions, that the universal interest is normative for the community taken together; any alternative will serve only some insufficiently extended sub-group, at the expense of others."). Further, for a consideration of whether the greatest good may be determined in an aggregative manner or whether egalitarian distribution is possible under utilitarian thought, see Robert Audi, Can Utilitarianism Be Distributive? Maximization and Distribution as Criteria in Managerial Decisions, 17 Bus. Етнісs Q. 593 (2007).
} 
society through permitting the enforcement of each type of restriction versus the cost incurred by employers, employees, and greater society. Where the benefits outweigh the costs, ensuring the greatest good, then there is an ethical basis for permitting mobility restrictions under utilitarian analysis.

\section{Noncompetes}

The costs and benefits of noncompetes to the past employer, employee, and future employer are suggested above. Briefly, the most obvious benefit is that it protects an employer from unfair competition in the case where a former employee would otherwise be able to take valuable knowledge that belongs to an employer and use it to assist a competing enterprise. Thus, it is also important that noncompetes allow the employer to increase the predictability of access to an important resource, in this case a human resource. ${ }^{173}$ Accordingly, the greater certainty of staffing that comes with an enforceable noncompete arguably encourages an employer to invest in the employee by investing in valuable human capital. ${ }^{174}$ Another reason why noncompetes are important to employers is that they can be used as a shield if they incorporate antipoaching or antiraiding provisions, which not only prohibit a former employee from competing but also stop the employee from decimating the former employer's workforce by hiring away the employer's most valuable employees. ${ }^{175}$ Nevertheless, such measures potentially constrain employees from taking their knowledge, skills, and productive capacity to the workplace where they will be most rewarded for utilizing them-whether this is in a competing firm or a personal entrepreneurial venture. In effect, a noncompete may prevent the dispersion of knowledge and its most productive use. ${ }^{176}$

\footnotetext{
${ }^{173}$ See generally Maureen B. Callahan, Comment, Post-Employment Restraint Agreements: A Reassessment, 52 U. CHI. L. REV. 703, 716-18 (1985) (arguing that noncompete agreements are the employer's only means of protecting its investment in human capital).

${ }^{174}$ See Bishara, supra note 72 , at 305 .

${ }^{175}$ See Anenson, supra note 87, at 2 ("In cases of employee poaching and mass defection, employers rely on the enforceability of anticompetitive covenants to protect themselves from such unscrupulous practices.").

${ }^{176}$ See Bishara, supra note 72 , at $306-07$.
} 
The more difficult questions to answer related to noncompetes deal with the costs and benefits incurred by society. ${ }^{177}$ Only legitimate business interests are to be protected and only for a limited time and space. The legal literature has addressed the public policy implications of noncompetes in a number of contexts, including their role in human capital investment $^{178}$ (particularly dealing with human capital in different industries), ${ }^{179}$ in fostering or impeding the rapid transfer of technology knowledge, ${ }^{180}$ and in top management contracts. ${ }^{181}$ Some law and economics literature, ${ }^{182}$ as well as business economics and management literature, ${ }^{183}$ has engaged in weighing the societal costs versus benefits of noncompetes.

This last area of scholarly work has recently seen an increase in empirical studies measuring the impact, if any, of noncompete enforcement on employee mobility, ${ }^{184}$ employee compensation and business

\footnotetext{
${ }^{177}$ Policy makers acknowledge that noncompetes are normally unenforceable as prima face anticompetitive and against public policy. See, e.g., Reed, Roberts Assocs. v. Strauman, 353 N.E.2d 590, 592-93 (N.Y. 1976).

${ }^{178}$ See Rubin \& Shedd, supra note 131.

${ }^{179}$ See Bishara, supra note 72 , at 318-19.

${ }^{180}$ See Ronald J. Gilson, The Legal Infrastructure of High Technology Industrial Districts: Silicon Valley, Route 128, and Covenants Not to Compete, 74 N.Y.U. L. REv. 575 (1999).
}

${ }^{181}$ See Stewart J. Schwab \& Randall S. Thomas, An Empirical Analysis of CEO Employment Contracts: What Do Top Executives Bargain For? 63 Wash. \& LeE L. Rev. 231, 254-57 (2006) (examining "the key legal characteristics of 375 employment contracts between some of the largest 1500 public corporations and their chief executive officers" and finding that about two-thirds include noncompete clauses that restrict chief executive officers' post-employment activities from one to five years, with an average duration of two years).

${ }^{182}$ See, e.g., Eric A. Posner \& George G. Triantis, Covenants Not to Compete from an Incomplete Contracts Perspective (Univ. of Chi. Law and Econ., Olin Working Paper No. 137, 2001), available at http://papers.ssrn.com/paper.taf?abstract_id=285805 (addressing the two objectives of ex post (labor mobility) and ex ante (human capital investment) efficiency and comparing noncompetes with the alternative contract breach remedies of specific performance and liquidated damages).

\footnotetext{
${ }^{183}$ See, e.g., Marx et al., supra note 81 (using a natural experiment created by a change in noncompete enforcement law to find lower rates of mobility under a policy of noncompete enforcement).
}

${ }^{184}$ See Fallick et al., supra note 81 ; Marx et al., supra note 81. 
investment, ${ }^{185}$ and entrepreneurial activity ${ }^{186}$ in various business and jurisdictional contexts. The results have been mixed. On the one hand, scholars have suggested that strong enforcement of noncompetes is good for the public interest because it leads to increased employer investment in human capital, which benefits society by leading to a better trained workforce. ${ }^{187}$ On the other hand, Alan Hyde has recently interpreted new empirical research on noncompetes to suggest that the economic harm to the restriction of labor mobility and knowledge transfer outweighs any benefits, concluding that all noncompetes should be banned, as in California. ${ }^{188}$ Moreover, because of asymmetries in the negotiating position between powerful employers and individual employees, there may be a tendency for employers to overreach in their noncompete terms. ${ }^{189}$

In addition, noncompetes are criticized simply for their anticompetitive nature. ${ }^{190}$ This is perhaps connected to concerns that noncompetes may cause economic harm via inefficient allocation of resources because these contracts restrict the free and rapid flow of labor. In other words, the criticism is that noncompetes allow one party to unfairly shift the burden of transaction costs related to restrictions to the weaker party, in this case the individual employee who is less able to bear the costs of compliance with the contract. In addition, some commentators perceive that " $[t] h e$ heightened scrutiny of employee noncompete agreements reflects some of the fundamental changes taking place in the economy and in the workplace." ${ }^{191}$ Specifically, noncompetes are problematic in the context of "the changing nature of the employment relationship, particularly the movement away from the traditional long-term employment relationship typical in the industrial age ... [and] the benefits of information sharing and employee mobility in the information age economy." ${ }^{92}$

\footnotetext{
${ }^{185}$ Garmaise, supra note 33 .

${ }^{186}$ Stuart \& Sorenson, supra note 81.

${ }^{187}$ Posner \& Triantis, supra note 182.

${ }^{188}$ Hyde, supra note 23, at 10-11.

${ }^{189}$ See, e.g., Stone, supra note 141 , at 740.

${ }^{190}$ See Bishara, supra note 72.

${ }^{191}$ Garrison \& Wendt, supra note 4, at 164.

${ }^{192} I d$. at 165 .
} 
In summary, states that allow employee noncompetes are, in effect, recognizing a public policy in favor of tempering free competition and mobility, to varying degrees, by allowing parties to contract for certain restrictions. Even if a noncompete will lessen otherwise lawful competition, and potentially inhibit the flow of knowledge, today most states will allow this compromise. However, the employer's extension of contractual control over a competitive human resource comes with potential harm for individual employees who may disproportionately bear the costs of protecting an employer's proprietary information, as well as potentially impeding the development of entrepreneurial competitive ventures.

\section{Inevitable Disclosure Doctrine}

The inevitable disclosure doctrine provides that "employers may enjoin a departing employee from taking a job on the grounds that he or she will 'inevitably disclose' some unspecified trade secret." ${ }^{193}$ Accordingly, an employer may restrict a former employee from joining a competitor if disclosure of confidential information would be inevitable in that new employment setting. Because it is not a contract-based remedy, an employer seeking inevitable disclosure protection essentially argues for a default rule to protect her intellectual property as captured in a trade secret. In effect, the employer is asking for a court to determine that a former employee will eventually, even unconsciously, divulge or otherwise use the trade secret in competition. As a result, the remedy is a prohibition on the former employee going to work for a competitor where it is assumed that the trade secret will surely be used sooner or later.

The problems with the doctrine from a utilitarian point of view are similar to the issues mentioned above with noncompete clauses. In fact, critiquing inevitable disclosure is more straightforward than a critique of noncompetes because the inevitable disclosure doctrine empowers an employer to restrict the employee's mobility when the employer did not even bargain for the restriction. ${ }^{194}$ The successful employer receives pro-

\footnotetext{
${ }^{193}$ Hyde, supra note 23 , at 9.

${ }^{194}$ See, e.g., Phillips, supra note 48, at 404 (“[C]ourts that grant injunctions in inevitable disclosure cases are in essence creating judicially crafted covenants not to compete. This runs contrary to the most fundamental principles of employment and contract law, as a contract term-one extremely harmful to the employee and quite beneficial to the employer-is forced upon the two parties in the absence of a bargained-for- agreement." (footnote omitted)).
} 
tection from competition indefinitely while the employee's ability to contribute to society by using knowledge and developing skills is limited. ${ }^{195}$ Thus the employer reaps all the benefits, while the employee and, indeed, society bear the costs. In addition, the inevitable disclosure doctrine constrains competition and may decrease knowledge diffusion that leads to subsequent innovation.

Perhaps worse, the implication is that the restriction on mobility is not bounded in time and scope like a noncompete term, which is subject to a reasonableness test. To the contrary, the information that is the subject of the trade secret in an inevitable disclosure action will be protectable-and thus so too the grounds to prevent the employee from moving freely-as long as the information remains a bona fide trade secret. ${ }^{196}$ This could lead not only to a temporary restraining order, causing a break in the employee's career, but also potentially to a permanent restraining order providing that the employee could not go to work for a certain company for a specified time. ${ }^{197}$ Moreover, this mechanism is obtained by burdening judicial resources and placing extra costs on both parties and on society. The employee is not paid for this required limitation in career opportunities and, because this is a judicially granted mechanism, the employee and the employer, as well as the judicial system, must endure the time and expense of litigation.

It seems as though the inevitable disclosure method is an attempt to put the champagne cork back in the bottle, a desperate attempt for the employer to protect assets when it neither adequately considered the need for protection ahead of time, nor engaged in adequate dialogue with the employee to resolve the issue to everyone's satisfaction. Proponents of using inevitable disclosure to restrict employee mobility assert that, because it is solely judicially administered, there is assurance that the protection will be granted only in legitimate, reasonable, and limited cases. ${ }^{198}$ However, from a public policy standpoint, the contrary argument could be made. The costs and benefits of this mechanism seem stacked in

\footnotetext{
${ }^{195}$ See Stone, supra note 141 , at 740.

${ }^{196} I d$.

${ }^{197} I d$.

${ }^{198}$ Garrison \& Wendt, supra note 4 , at $178-85$.
} 
favor of the employer to the detriment of the employee's interests in benefiting from the use of her skills and knowledge, as well as society's interests as a whole in benefiting from an economy based on healthy competition and the diffusion of knowledge that can lead to innovation. If it became the standard mechanism to require judicial intervention to resolve termination of employment when trade secrets are at issue, it could place an enormous burden on judicial resources, without creating a net benefit for society as a whole. ${ }^{199}$ One would hope this doctrine would be used only very rarely and cautiously when there are no other options to protect legitimate proprietary business information. It would be preferable for the primary mechanism used to resolve these disputes to be one that encourages the parties to negotiate a mutually satisfactory resolution within appropriate limits that does not unduly burden the greater interests of society. This might be the strength of the garden leave mechanism, discussed next.

\section{Garden Leave}

Garden leave is like a noncompete in that it protects an employer's interest in information by prohibiting mobility, but it has the extra advantage of forcing the employer to bear those costs post-employment, which compensates the employee. ${ }^{200}$ From a legal and economic perspective, Cynthia Estlund has pointed out that with garden leave an

employer gets the same protection as a similar period of "non-competition," [as with a noncompete] but must bear the primary economic burden itself rather than casting it on the employee. Employees' postemployment activities

\footnotetext{
${ }^{199}$ See William Lynch Schaller, Secrets of the Trade: Tactical and Legal Considerations from the Trade Secret Plaintiff's Perspective, 29 Rev. Litig. 729, 809-10 (2010) ("The very point of injunctive relief is to prevent injury and damages by preemptive court intervention-in effect, remedium absque injuria: a remedy without injury. Trade secret inevitable disclosure claims are, in fact, classic examples of this principle." (citations omitted)); William Lynch Schaller, Trade Secret Inevitable Disclosure: Substantive, Procedural \& Practical Implications of an Evolving Doctrine (Part I), 86 J. Pat. \& Trademark Off. Soc'y 336, 341-43 (2004) (reviewing the cost implications of numerous trade secret cases).

${ }^{200}$ See Raker, supra note 169, at 752 (finding that "recent decisions suggest that courts are more likely to enforce a restriction provision where the company alleviates the effect of the former employee's 'loss of livelihood' by paying the former employee during the noncompete period").
} 
are still restricted; some opportunities may dry up and some employee knowledge may grow stale during the period of enforced idleness. ${ }^{201}$

However, she also observes that "the garden leave device has the virtue of forcing employers to internalize the primary cost of restrictions on employees' post-employment activities, and thus to think twice about whether and how long they are willing to do so." ${ }^{202}$ Put another way, the obvious cost of paying an employee not to work inserts the discipline of the price mechanism into the employer's decision making, which provides the employer with an incentive to pay to restrict the mobility only of highly valuable employees and to do so for the shortest length of time that will protect valuable knowledge from being transferred immediately.

Even though there are benefits associated with garden leave over noncompetes or inevitable disclosure, there are also drawbacks. The garden leave clause seems less amendable to reasonableness scrutiny by policy makers and may still act as an improper restraint on trade. It may also allow employer overreaching, provided that the employer is willing to pay to overreach. ${ }^{203}$ It is still restrictive from a public policy perspective, in that the public is denied the beneficial services, innovation, and knowledge of the worker for a period of time. The worker is not being a productive member of society-even if she is not being denied compensation to refrain from competition. Moreover, though the worker is getting paid to lock up her skills, she is potentially harmed by not having her skills remain sharp and relevant. ${ }^{204}$ Shareholders also may complain that the firm is paying someone not to work and receiving no tangible value in return. There are business issues with that type of waste. Nonetheless, this cost is arguably a good investment because it reduces the otherwise likely transfer of time-sensitive knowledge, skills, and relationships to a competitor. Finally, garden leave is fundamentally an anticompetitive mechanism that could lead to abuse, albeit perhaps less than the other two.

\footnotetext{
${ }^{201}$ Estlund, supra note 107, at 425.

${ }^{202} I d$.

${ }^{203}$ Hepple, supra note 108 , at 214-15.

${ }^{204} I d$. ("The courts have recently become concerned about the possible abuse of garden leave. They have declined to grant injunctions unless there is an express clause prohibiting work for a rival during the notice period, and have been willing to imply an obligation on the employer to provide work during the notice period, particularly if the employee requires work to maintain skills and experience.").
} 


\section{Fairness Analysis}

Rawls's ethical theory centers on justice and fairness in the design and evaluation of social institutions. ${ }^{205}$ Scholars holding the traditional narrow view of the applicability of Rawls's "basic structure" of society generally reserve Rawlsian analysis for public law issues such as basic constitutional liberties and systems of tax and transfer, rather than private law issues such as provisions of employment contract law. ${ }^{206}$ In this view, contracts are seen as a private outcome of promises made between specific parties, where there is little role for an analysis of overall social fairness. However, Rawls's own writings are ambiguous as to which social institutions are appropriately evaluated in terms of fairness in the basic structure ${ }^{207} \mathrm{~A}$ broader view asserts that Rawlsian analysis of justice as fairness can legitimately be applied to systems of private law such as the body of laws governing contracts. ${ }^{208}$ In a Rawlsian analysis, "contract law would be constructed such that, when viewed in conjunction with all other legal and political institutions, it best serves the demands of the principles of justice." ${ }^{209}$ For purposes of this discussion, we will take the broader view and use a simplified Rawlsian analysis to explore restrictions on employee mobility as part of the social institution of employment law.

To consider the fairness of various legal institutions controlling the mobility of employees-including contractual noncompete clauses, the inevitable disclosure doctrine, and garden leave-we engage in a Rawlsian thought experiment. Thus we imagine ourselves in the "original position" behind a "veil of ignorance," ${ }^{110}$ not knowing whether we would be an employer seeking to protect business assets from unfair competition, an employee seeking to preserve her freedom of movement, or a startup firm

\footnotetext{
${ }^{205}$ John Rawls, Justice as Fairness: A Restatement (Erin Kelly ed., 2001).

${ }^{206}$ See generally Kevin A. Kordana \& David H. Tabachnick, Rawls and Contract Law, 73 Geo. WASH. L. REv. 598 (2004) (expanding the conventional Rawlsian view of private law).

${ }^{207} I d$. at 604-05 (citing Thomas W. Pogge, Realizing Rawls 21-23 (1989)); id. at 604 n.26 (quoting Pogge, supra ("Rawls leaves this notion [of the basic structure] not merely vague but also ambiguous.")).

${ }^{208} I d$. at $624-25$ (concluding that a democratically elected legislature is charged with enacting legislation that is just and fair, according to a Rawlsian basic structure).

${ }^{209}$ Kordana \& Tabachnick, supra note 206, at 623.

${ }^{210}$ Rawls, supra note 205 , at 42 .
} 
looking to hire experienced staff. The parties would not know what type of business assets would require protection, nor the nature of the competitive market. Moreover, the parties would not know the skill level of the employee, the nature of the labor market, or the relative bargaining power of employer and employee.

In this thought experiment, we seek to establish a social order with impartial and rational principles, including the liberty principle, which assumes that all persons are free and equal, ${ }^{211}$ and the difference principle, which permits social and economic inequalities as long as the least advantaged members of society are benefited. ${ }^{212}$ The difference principle would not be applied on a transaction-by-transaction basis, rather the idea is to establish "a set of rules that, when applied generally, is instrumental to the overall scheme of legal and political institutions that maximizes the position of the least well-off, as compared to other possible schemes." ${ }^{213}$ From behind the veil of ignorance, we want to determine reasonable mechanisms for employers to protect valuable firm assets, such as strategic knowledge and information from unfair competition, which would also protect an employee's ability to sell her labor services in an open market where they would be utilized at their highest value. From a societal perspective we might want to balance the growth and innovation benefits of a high-velocity labor market ${ }^{214}$ with a degree of stability and certainty in outcomes. $^{215}$

\section{Noncompetes}

As noncompete agreements are contractual clauses that can be negotiated between the parties, they could be ideal for protecting the interests of

\footnotetext{
${ }^{211} I d$.

${ }^{212} I d$.

${ }^{213}$ Kordana \& Tabachnick, supra note 206, at 626.

${ }^{214}$ Hyde, supra note 23, at 6-11.

${ }^{215}$ See generally Richard Nielsen, High-Leverage Finance Capitalism, the Economic Crisis, Structurally Related Ethics Issues, and Potential Reforms, 20 Bus. Етнісs Q. 299, 325-26 (2010) (suggesting that society is better off when rapid change from evolutionary forms of capitalism is balanced with social controls and that in this way "we may be able to realize Schumpeter's vision of 'creative destruction' with less destruction and social inequality as well as Aristotle's ideal of creating wealth in such a way as to make us better people and the world a better place").
} 
employers while preserving the rights of employees. But, as applied, noncompete clauses are often unilateral mechanisms that force employees to bear the primary burden and that allocate the benefit to established employers. Because the burden of the noncompete is externalized by the employer onto the employee, employers have an incentive to overreach. Thus, in the original position from behind a veil of ignorance, the question arises whether the interests of the most vulnerable populations are protected by this practice. Differences in bargaining power lead to employees signing noncompete clauses that are detrimental to their interests simply because they have limited alternate options. ${ }^{216}$ This concern is underlined by instances of noncompete agreements being enforced against involuntarily terminated or low-skilled employees who have few opportunities for alternative employment. ${ }^{217}$

The effort by some state legislatures to narrow the applicability of noncompetes to only skilled, high-earning employees is one potential solution, as these individuals are more likely than low-earning employees actually to have access to business information worthy of protection. ${ }^{218}$ This solution might be fairer to employees; however, it could potentially increase the anticompetitive impact on society precisely because skilled employees are most likely to innovate and create startup enterprises. Finally, one negative point for employers is the uncertainty involved in whether proprietary business information will actually be protected because employers are dependent on the courts to enforce noncompetes when employees resist them. Because of these issues, under a Rawlsian analysis, it seems clear that use of noncompete clauses to protect competitive business information would not be the fairest mechanism to any of the parties, particularly to the most vulnerable.

\footnotetext{
${ }^{216}$ For a discussion of these issues, see supra notes 130-32 and accompanying text.

${ }^{217}$ See generally Kenneth J. Vanko, "You're Fired! And Don't Forget Your Non-Compete ....": The Enforceability of Restrictive Covenants in Involuntary Discharge Cases, 1 DePaul Bus. \& Com. L.J. 1 (2002) (examining covenants not to compete in the context of an involuntary termination and concluding that courts should employ a balancing of the equities approach to give consideration to the nature of the discharge in conjunction with all other relevant factors).

${ }^{218}$ See Colo. Rev. STat. \$ 8-2-113(2) (2010) (limiting enforcement of employee noncompete covenants to "[e]xecutive and management personnel[,] and officers and employees who constitute professional staff to executive and management personnel"). Interestingly, the proposed noncompete reform legislation in Massachusetts sets a specific employee salary floor of $\$ 125,000$ for noncompete enforcement. See Brownsberger, supra note 77 .
} 


\section{Inevitable Disclosure Doctrine}

In some ways, this doctrine raises even more concerns than noncompetes related to fairness because it does not require prior notice to or the consent of the employee. Nevertheless, some commentators find the inevitable disclosure doctrine superior to noncompetes. ${ }^{219}$ The upside of this doctrine is that it is crafted and enforced by judges who can carefully tailor the application of the doctrine to protect specific business information, while allegedly ensuring against overreaching, which can have a chilling effect on an employee's mobility. ${ }^{220}$ Thus this doctrine may be more balanced and equitable, with judges assuring the protection of the interests of the most vulnerable.

However, there are several downsides of the inevitable disclosure doctrine. First of all, justice for employers is uncertain as they will not know whether their competitive information will be protected until the resolution of the process. This mechanism is even more dependent on judicial enforcement than noncompetes. For employees who are precluded from employment options as a result of the application of this doctrine, fairness of the outcome may be questionable as the remedy is often not temporary, but rather a permanent injunction. As the new psychological employment contract more frequently asks employees to provide for their own futures and bear the risks of economic cycles, ${ }^{221}$ the burden of limited employment options might fall quite heavily on an employee. Thus, looking at the inevitable disclosure doctrine as a social system of employment law, Rawls might find it to fall short in the application of the difference principle. The social and economic inequalities inherent in this mechanism do not tend to maximize the position of the least-advantaged members of society.

\footnotetext{
${ }^{219}$ See Garrison \& Wendt, supra note 4, at 186 (proposing that trade secret protection should be decoupled from employee noncompete law, no longer being considered a legitimate justification for an employee noncompete agreement). According to Garrison and Wendt, "Trade secrets would continue to be protected from actual or threatened misappropriation under confidentiality agreements and trade secret laws. Most importantly, courts would be empowered to prevent employment of a former employee under the inevitable disclosure doctrine." Id.

${ }^{220} I d$. at 160.

${ }^{221}$ Katherine V.W. Stone, Legal Regulation of the Changing [Employment] Contract, 13 Cornell J. L. \& Pub. Pol'y 563, 570-71 (2004).
} 


\section{Garden Leave}

Given that the foundation of a Rawlsian analysis is to find a solution for the structure of society that all parties can agree upon regardless of their position in society, there are many reasons why garden leave might be preferable to the others. There are several benefits of garden leave. First, it is neither unilateral nor court determined, but rather a negotiated agreement, where the benefits and burdens are shared by the employer and employee. While the employer receives protection of proprietary business information for the agreed amount of time, the employee is compensated for the lack of livelihood during that period. The burden is not externalized by the employer (as with noncompetes), but a cost for exercising this mechanism-the cost of the continued salary of the employee-is borne directly by the employer rather than some state-based unemployment insurance. ${ }^{222}$ Thus, the party that is usually more vulnerable is afforded greater protection in this case than in any other type of mobility restriction because the employee's livelihood during the relevant period is ensured as part of the mechanism. As a result, an employer has an incentive to tailor and limit the garden leave to only the amount of time that is relevant to the specific position and business knowledge gained by the employee.

When it comes to social impacts, garden leave, like noncompetes and inevitable disclosure, has negative social impacts related to restraints on innovation as a result of limited labor mobility and knowledge transfer. However, with this mechanism it remains possible for the employer to protect resources that it values. Because garden leave involves a negotiated solution that shares costs and benefits between the parties, Rawls's liberty principle supporting the freedom and equality of all parties is upheld. For these reasons, while there are still weaknesses, a Rawlsian analysis of employment mobility mechanisms is likely to favor garden leave over other options.

\section{Comparison of Mechanisms}

We have identified various strengths and weakness of the three mechanisms for restricting employee mobility from the perspectives of rights, utilitarian, and fairness ethical reasoning. These perspectives give a fuller

\footnotetext{
${ }^{222}$ See Lembrich, supra note 103, at 2317-18.
} 
consideration of the three elements of the reasonableness test applied by courts for the enforcement of noncompete clauses.

Two questions remain to be discussed in this article. First, in comparing the analyses of the three mechanisms, while each has shortcomings, is there one mechanism that should be promoted more than the others from a public policy perspective? In other words, on the individual level, which mechanism should an ethical manager choose to use? Second, what improvements can be suggested in the application of each of these mechanisms to counter the problems identified herein? We will wrap up this section on the ethics critique of restrictions on employee mobility by discussing which is the preferable mechanism. Then, we will address the second question in our recommendations in Part IV.

In our assessment, garden leave, which seems to be relatively new to the United States, generally provides an improvement over the existing structure of judicial enforcement of noncompete clauses or the inevitable disclosure doctrine. The main weaknesses of the garden leave doctrine are the required idleness on the employee's part that likely results in a loss of productivity to the detriment of corporate shareholders and society overall, as well as the employee's potential loss of skill sharpness. Nevertheless, from a rights perspective, garden leave seems best to protect the fundamental rights and legitimate interests of both employers and employees. Employers can preserve their property rights to proprietary information. Employees preserve their freedom to exercise and develop their productive capacity. The recognition of rights and obligations of both parties is inherent in the garden leave mechanism and may serve to promote a basis for mutually agreeable compromise, finding a way to protect the important rights of both parties.

From a utilitarian perspective, by protecting the employer's proprietary information only to the extent that the employer is willing to pay the employee to remain idle, the price mechanism inherent in a garden leave provision provides a way to optimize the cost-benefit analysis. This has the benefit of providing the specific degree of security that the employer requires to continue to invest in knowledge development. As a result, the long-run social cost is lessened when the employee is more quickly able to deploy to her desired position, though there is a temporary decrease in productivity during the leave period. Moreover, garden leave also limits the restriction on competition and knowledge diffusion within society to a temporary period, as well as reduces the costs of using scarce judicial resources. From a utilitarian perspective, garden leave may provide 
greater benefits to the employer, the employee, and to society as a whole, while limiting the costs borne by each party. Thus, garden leave provides for a greater good relative to the other two types of mobility restrictions.

Finally, from a Rawlsian perspective, garden leave is the mechanism most likely to create a social order that ensures equality while protecting the interests of the most vulnerable. The burden of protecting the employer's interest in proprietary information is shared by both parties rather than wholly externalized by the employer because the employer pays the employee for the agreed upon period of idleness during which the employee agrees not to use or develop her skills on behalf of a competitor. This structure of private contract law may result in a more just social order than either of the other two mechanisms.

From a business ethics perspective, while garden leave also has its flaws, it may be most preferable for policy makers, employee interest groups, and managers to encourage the use of garden leave policies. While we provide more specific recommendations below relative to limiting the weaknesses inherent to each of the three employee mobility restriction mechanisms, overall, we assert that legislatures considering regulations on employee mobility restrictions and drafters of the Restatement of Employment Law may wish to consider encouraging garden leave as the preferable mechanism for protecting the interests of both parties and society as a whole. Further, managers seeking to implement ethical business practices may favor garden leave policies above other types of mobility restrictions.

\section{ReCOMmendations For POLiCy Makers}

We have reviewed three mechanisms for restraining employee mobility and protecting employer proprietary information and scrutinized each using various business ethics frameworks. First, we examined these mechanisms from a property rights-based view, which emphasizes the employer's right to protect its business assets and the employee's right of control over her labor. Second, we applied a utilitarian account of the costs and benefits to employers, employees, and society of the three mechanisms. Finally, we applied a Rawlsian perspective to analyze the equity and fairness of each mechanism, with an eye on reducing the negative impact on the most vulnerable individuals in the employment relationship.

Our analysis shows that each mechanism is problematic in its own way. Accordingly, a court or state legislature wishing to advance any of the 
ideals (achieving fairness, maximizing social benefits, or protecting property rights) needs to recognize the shortcomings of each. In this section, we offer recommendations to policy makers to overcome some of the shortcomings inherent in each of the employee mobility restraint mechanisms, while still recognizing the importance of protecting proprietary business information. In general, we suggest that it would be most desirable for all persons concerned (except perhaps litigators who specialize in employment termination lawsuits) if the preferred mechanism protecting business proprietary information would prioritize open communication, mutual understanding, and negotiation between employers and employees rather than unilateral or judicially imposed obligations.

The noncompete mechanism seems to inadequately protect individuals' rights, because of the bargaining asymmetries inherent in the inception of the agreement. Noncompete enforcement is also subject to abuse by employers who are generally in a more powerful bargaining position. For instance, the employer can use the mere threat of litigation over a noncompete to chill the employee's desire to move to a competitor or to start a competing enterprise. ${ }^{223}$ Post-employment enforcement also leaves the employee uncompensated by the employer and unable to earn a living working in her preferred position. ${ }^{224}$ Essentially, the employer has little cost incentive not to overreach and try to enforce the greatest restriction on mobility possible, at the expense of the employee's property rights.

Noncompete policy can be changed to remedy these issues and better achieve ethical ideals. For example, limiting the level of employee who may be subject to noncompetes might help address property rights concerns. In addition, specific rules limiting the types of business information that may be covered by a noncompete may better ensure that the benefits employers gain by enforcement of noncompetes outweigh the social costs of constrained competition. Finally, the process by which noncompetes are established may be reformed to better achieve fair and equitable outcomes.

All states that permit noncompetes should limit their applicability solely to employees who are most likely to have possession of proprietary business information that is sufficiently valuable to require protection. For

\footnotetext{
${ }^{223}$ See DiMatteo, supra note 54, at 765 (discussing the potentially coercive use of noncompetes by employers). Professor DiMatteo argues that employee noncompetes have "two strategic purposes: proprietary protection and strategic coercion," with "[t]he second purpose seek[ing] to deter employee movement to a competitor." Id.

${ }^{224}$ See Stone, supra note 141 , at 742.
} 
instance, proposals in Massachusetts and Illinois seek to limit the type of employees who may be covered by a noncompete to highly compensated and business-crucial employees. ${ }^{225}$ In addition, for over three decades, Colorado's noncompete statute has limited noncompete enforcement to "[e]xecutive and management personnel[,] and officers and employees who constitute professional staff to executive and management personnel." ${ }^{226}$ For other jurisdictions interested in limiting the coverage of noncompetes to employees whose mobility to a competitor may be cause for legitimate concern, this coverage could be determined, for example, by setting a limitation based on the employee's rank, salary, or expertise. Along this line of thinking, the type of business information that is protected by noncompetes should be limited to truly proprietary information that is strategically relevant to the firm's competitive competency.

Finally, the process of entering into a noncompete agreement should be regulated to ensure that there is no question that employees fully consent to the noncompete clause. At the outset, when the parties are negotiating all the relevant aspects of the job or of a promotion, such as salary and duties, the employer should be required to disclose the terms that will be required of the employee. Arnow-Richman suggests courts could accomplish this if they simply refused jurisdiction over noncompete agreements that were not signed as part of the primary negotiation for the job. ${ }^{227}$ While noncompetes can be an important mechanism to protect business proprietary information, limiting them in these ways would cut down on litigation.

The doctrine of inevitable disclosure is perhaps even more antithetical to an employee-rights or fairness-based ethical perspective. Specifically, the doctrine restricts the post-employment mobility of the employee as does the noncompete, but it does so without clearly defined temporal parameters. The theory is that the trade secret in the employee's possession is always at risk of disclosure if the employee works for a competitor. The doctrine can arise in the absence of a noncompete or any other

\footnotetext{
${ }^{225}$ See supra notes $77-78$.

${ }^{226}$ See Colo. Rev. Stat. § 8-2-113(2) (2010).

${ }^{227}$ Arnow-Richman, supra note 137, at 657 (calling for disclosure in employment contracts comparable to that called for in consumer protection law such that "[e]ither through common law or statutory initiative, any term withheld until after the employee's acceptance of the initial offer would be unenforceable if the term could have been provided as part of the hiring process").
} 
contractual agreement. Thus, on its own, an imposition of an inevitable disclosure-based injunction prohibits an employee's mobility, requiring neither the employee to consent to the restriction nor the employer to negotiate or pay for it. As a result, the employee cannot work for a competitor-perhaps indefinitely-yet never accepted the restriction nor received compensation for it. The balance clearly shifts to the employer at the expense of the employee's property rights.

The doctrine of inevitable disclosure is also antithetical to the idea of maximizing social benefit. In terms of the potential benefits to society, this mechanism does not reward businesses that act with foresight to protect business secrets and seek common ground with employees. Rather it rewards firms that have no other way to protect valuable trade secrets. In terms of costs to society, the fact that this doctrine is solely judicially enforced means that if it became a universal practice, significant judicial resources could be tied up in this mechanism (making employment litigators the most satisfied beneficiaries).

To improve this mechanism in a manner to better achieve ethical ideals, the application of the doctrine of inevitable disclosure should be limited. Specifically, courts could ensure greater fairness and equity in the judicial process when applying the inevitable disclosure doctrine by limiting who could be subject to the doctrine (to better protect property rights) and specifying what subject matter it can cover (to maximize benefits while minimizing social costs). As with noncompetes, only high-level employees who are proven to have possession of high-level proprietary business information should be subject to such injunctions. Further, the employer should have to establish that the information actually possessed by the employee is sufficiently valuable to require protection. In other words, it should cover only truly proprietary information that is strategically relevant to the firm's competitive position and core competency. Finally, in terms of process, before a judge can impose an injunction, there should be some evidentiary requirement establishing that the employer has already met a very high standard for enacting measures to protect its business proprietary information. Such measures could include things such as regularly requiring employees to sign confidentiality agreements; seeking and defending legal intellectual property protection for any business information, processes, and knowledge that are subject to federal patent, trademark, copyright, and trade secret rules; and limiting which employees have access to full knowledge about key proprietary business processes, secret recipes, and client lists. In order to conserve rare judicial resources, 
the burden of proof to obtain an injunction based on the doctrine of inevitable disclosure must be sufficiently high to establish that all other mechanisms to protect business information have been attempted and this really is the last resort.

Of the three mechanisms, garden leave seems to be on better ethical grounds in terms of the fairness and equity provided to the departing employee. With garden leave the employer internalizes the cost of enforcing a restriction on employee mobility. Thus, the price mechanism ensures that the potential power-abusing party (the employer) will restrict only behavior that it thinks is truly worth purchasing and creates an incentive to limit the period of mobility prohibition. When the employer willingly, if begrudgingly, bears those costs after the employee leaves, it becomes clearer that removing the employee from the labor market has tangible costs. With garden leave the employer will more likely accurately value the true costs of restricting mobility and have an economic incentive to refrain from overreaching or any vindictive behavior. As compared to the bluntness of a noncompete for restricting unfair competition, garden leave may actually sharpen the focus on the issues related to competitiveness and specific employees' financial value to a firm.

Thus, with garden leave there is an ethically sound balance struck between the individual rights of the employee to restrict the sale of her labor and the employer's protectable interest in curtailing unfair competition. The Lockean concern about abuse of the employee's property rights is alleviated because garden leave creates a market for the employee's services, values them accordingly, and compensates the employee. Like the noncompete negotiation, but now with a market valuation component, the employee retains some power to sell her labor (i.e., choose to work for a competitor) but does so on more balanced terms. Moreover, the incentives align for the employer not to overreach, because it is forced to pay for any immobility it "purchases" during the garden leave period. For these reasons, the concerns about which employees and what information the garden leave captures and restricts appear to become less dire. Just as with noncompetes the employer should disclose the terms that will be required of the employee at the outset, when the parties are negotiating all the relevant aspects of the initial employment or subsequent promotion such as salary and duties, in order to ensure there is no question that an employee fully consents to a garden leave clause. In addition, the garden leave clause could include a mediation requirement in the event of disagreement about its application, which would ensure that open commu- 
nication, mutual understanding, and negotiation between employers and employees would be prioritized over unilateral or judicially imposed obligations.

\section{CONCLUSiON}

Legislatures and judges have sought to find the socially optimal balance of the tensions between the desire for freedom of employee mobility and the need to protect business information that creates competitive advantage. Nationwide, legal decisions run the gamut in terms of regulations and rulings permitting or prohibiting employee mobility restraint mechanisms such as noncompetes, the doctrine of inevitable disclosure, and garden leave. While these legal opinions or legislative developments may refer generally to concepts such as property rights, utilitarian analyses, and fairness, we hope that this review of the ethical and philosophical bases for these concepts might provide a much-needed context to support policy development.

Moreover, this analysis helps to address a gap in the literature on the evaluation of ethical issues related to employee mobility restraints. The discussion above may inform the debate on the appropriateness and legitimate scope of these measures. This analysis may support future researchers not only in their work with these specific legal mechanisms but also perhaps more broadly in evaluating property rights, balancing costs and benefits, and determining fairness in the context of a knowledge-based economy. 